\title{
PROGENITOR CELLS IN AURICULAR CARTILAGE DEMONSTRATE CARTILAGE-FORMING CAPACITY IN 3D HYDROGEL CULTURE
}

\author{
I.A. Otto ${ }^{1,2, *}$, R. Levato ${ }^{1}$, W.R. Webb ${ }^{3}$, I.M. Khan ${ }^{3}$, C.C. Breugem ${ }^{2}$ and J. Malda ${ }^{1,4}$ \\ ${ }^{1}$ Department of Orthopedics, University Medical Center Utrecht, the Netherlands \\ ${ }^{2}$ Department of Plastic Reconstructive Surgery, University Medical Center Utrecht, the Netherlands \\ ${ }^{3}$ Center for Nanohealth, School of Medicine, Swansea University, Wales \\ ${ }^{4}$ Faculty of Veterinary Sciences, Utrecht University, the Netherlands
}

\begin{abstract}
Paramount for the generation of auricular structures of clinically-relevant size is the acquisition of a large number of cells maintaining an elastic cartilage phenotype, which is the key in producing a tissue capable of withstanding forces subjected to the auricle. Current regenerative medicine strategies utilize chondrocytes from various locations or mesenchymal stromal cells (MSCs). However, the quality of neo-tissues resulting from these cell types is inadequate due to inefficient chondrogenic differentiation and endochondral ossification, respectively. Recently, a subpopulation of stem/progenitor cells has been identified within the auricular cartilage tissue, with similarities to MSCs in terms of proliferative capacity and cell surface biomarkers, but their potential for tissue engineering has not yet been explored. This study compared the in vitro cartilage-forming ability of equine auricular cartilage progenitor cells (AuCPCs), bone marrow-derived MSCs and auricular chondrocytes in gelatin methacryloyl (gelMA)-based hydrogels over a period of $56 \mathrm{~d}$, by assessing their ability to undergo chondrogenic differentiation. Neocartilage formation was assessed through gene expression profiling, compression testing, biochemical composition and histology. Similar to MSCs and chondrocytes, AuCPCs displayed a marked ability to generate cartilaginous matrix, although, under the applied culture conditions, MSCs outperformed both cartilage-derived cell types in terms of matrix production and mechanical properties. AuCPCs demonstrated upregulated mRNA expression of elastin, low expression of collagen type $\mathrm{X}$ and similar levels of proteoglycan production and mechanical properties as compared to chondrocytes. These results underscored the AuCPCs' tissue-specific differentiation potential, making them an interesting cell source for the next generation of elastic cartilage tissue-engineered constructs.
\end{abstract}

Keywords: Auricular cartilage, tissue engineering, cartilage progenitor cells, hydrogel, 3D culture.

*Address for correspondence: J. Malda, P.O. Box 85500, 3508 GA, Utrecht, the Netherlands. Telephone: +31 887551133 Email: j.malda@umcutrecht.nl

Copyright policy: This article is distributed in accordance with Creative Commons Attribution Licence (http://creativecommons.org/licenses/by-sa/4.0/).

\section{Introduction}

A significant challenge in cartilage tissue engineering is the recruitment of a sufficient number of cells for the generation of large tissue constructs (Bichara et al., 2012). The necessity for larger constructs is exemplified by the case of auricular reconstruction required for the congenital disorder microtia and for defects of the auricle caused by injury and disease. For the human auricle, estimates of the number of cells required for tissue regeneration range between 100 and 150 million (Bichara et al., 2012), with the obvious challenge of obtaining this number of cells from an autologous source.

Although considerable progress has been made using a variety of cells for auricular cartilage tissue engineering, there is no definitive conclusion on which cell type is capable of providing the most favorable clinical outcome for tissue-engineered cartilage constructs. Originating from the native tissue, chondrocytes are a logical cell source for the generation of neocartilage. Auricular (Bichara et al., 2014; Cao et al., 1997; García-López et al., 2015; Isogai et al., 2006; Kusuhara et al., 2008; Nakao et al., 2017; Papadopoulos et al., 2011; Park et al., 2004; Pomerantseva et al., 2016; Reiffel et al., 2012; Sanz et al., 2007; Tseng et al., 2014; Xu et al., 2005), microtia (Ishak et al., 2015; Kamil et al., 2004b; Nakao et al., 2017), nasoseptal (Ávila et al., 2015; Bichara et al., 2010; Haisch et al., 2002; Isogai et al., 2006; Kusuhara et al., 2008), costal (Isogai et al., 2006; Kusuhara et al., 2008) and articular chondrocytes (Isogai et al., 2006; 
Kamil et al., 2004a; Kusuhara et al., 2008; Mizuno et al., 2014) are all used for tissue-engineering auricular cartilage. Specific characteristics and ability for chondrogenesis can differ depending on the origin of the chondrocytes. Where the articular and costal cartilage are of mesenchymal origin, the developmental origin of the auricular cartilage of the pinna is still controversial. The auricle originates from two pharyngeal arches that have contributions from all three embryonic layers (Wright, 1997; Graham, 2001; Luquetti et al., 2011; Tracy et al., 2013). Nevertheless, fully differentiated cells from various cartilage origins generally demonstrate the capacity to produce cartilage-like extracellular matrix in vitro and in vivo (Ahmed and Hincke, 2014; Bichara et al., 2010; Isogai et al., 2006; Kusuhara et al., 2008; Pleumeekers et al., 2013). However, only a small amount of tissue can be harvested from the patient, requiring extensive in vitro expansion of the isolated cells to obtain a sufficient cell's number for the production of clinically-relevant tissue-engineered cartilage constructs. The proliferative potential of chondrocytes is naturally low (Phull et al., 2016) and their cartilage-forming ability is known to decline with extended cultivation (Homicz et al., 2002; Schnabel et al., 2002). In fact, repeated passaging of chondrocytes induces the loss of their chondrogenic phenotype (Saadeh et al., 1999) and, ultimately, leads to progressive dedifferentiation. To some extent, re-differentiation can be attained under specific culture conditions, e.g. in three-dimensional (3D) environments (Benya and Shaffer, 1982) and in the presence of appropriate growth factors (Jakob et al., 2001; van Osch et al., 2001), yet the revenue is limited (van Osch et al., 2001). The resulting neo-tissue is often of a fibrocartilagenous quality and exhibits inferior biochemical and mechanical properties as compared to native cartilage tissue (Chung et al., 2006; Demoor et al., 2014; Nabzdyk et al., 2009; Williams et al., 2010). In the past decade, stem cells have gained increasing interest for tissue engineering applications because of their capacity for self-renewal and multilineage differentiation. For example, bonemarrow-derived mesenchymal stromal cells (MSCs) can be extensively expanded (Gardner et al., 2013) and demonstrate the ability to differentiate into various cell types, including chondrocytes, osteoblasts and adipocytes (Pittenger et al., 1999). Numerous studies have successfully used MSCs for the generation of cartilage (Cheng et al., 2014; Seda Tigli et al., 2009; Vinardell et al., 2012), sometimes in co-culture with auricular chondrocytes (Liu et al., 2010; Pleumeekers et al., 2015; Zhao et al., 2016). Nevertheless, the risk of hypertrophic growth, terminal differentiation and subsequent tissue calcification remains an important limitation when using MSCs for cartilage tissue engineering (Williams et al., 2010; Gawlitta et al., 2010). In addition, bone marrow-derived MSCs are not involved in the development of native auricular cartilage and are, as articular, costal and nasoseptal chondrocytes, not predisposed to produce the elastic fibers required for this elastic-type cartilage (Kusuhara et al., 2008).

Tissue-derived stem/progenitor cells exhibit stem-cell-like qualities, such as self-renewal and multipotency, yet are embedded within the target tissue in niches and are primed to differentiate to that tissue (Jayasuriya and Chen, 2015). The identification of resident progenitor cell populations in articular cartilage (Dowthwaite et al., 2004; Williams et al., 2010) as well as in auricular and tracheal perichondrium (Derks et al., 2013; Kobayashi et al., 2011b; Togo et al., 2006) has opened up new pathways for cartilage tissue engineering. Like MSCs, which can undergo up to 70 population doublings (Christodoulou et al., 2013), cartilage progenitor/stem cells retain proliferative ability for up to 60 population doublings (Williams et al., 2010), demonstrating potential for accumulating large cell numbers starting from a single cell. In addition, the cells maintain multipotent differentiation ability while expressing chondrocytespecific characteristics (McCarthy et al., 2012). It is hypothesized that these tissue-specific progenitor cells are highly primed to differentiating into the chondrogenic lineage (Jayasuriya and Chen, 2015; McCarthy et al., 2012).

Auricular cartilage tissue engineering may benefit greatly from a source of tissue-specific cells that can be expanded up to large numbers without losing their differentiation potential. Nevertheless, the auricular cartilage itself was, until recently, unknown to harbor a progenitor cell population. The presence of colonyforming, multipotent progenitor cells in auricular cartilage has recently been confirmed (Xue et al., 2016), though these cells have not yet been explored for a tissue-engineering purpose. The objective of the current study was to evaluate the cartilage-forming ability of such auricular cartilage progenitor cells in a 3D hydrogel culture. It was hypothesized that these cells, despite in vitro expansion, could outperform auricular chondrocytes and bone-marrow-derived MSCs with regards to production of auricular cartilage.

Mimicking the hydrated environment of native cartilage, hydrogels are particularly attractive for cartilage regenerative strategies. Gelatin methacryloyl (gelMA)-based hydrogels are a versatile group of biomaterials shown to facilitate cartilage-like matrix production for chondrocytes, articular cartilage progenitor cells as well as MSCs, supporting both cell viability and mechanical properties (Levato et al., 2017; Daly et al., 2016; Gao et al., 2015; Schuurman et al., 2013). In this study, cell-laden gelMA hydrogels were cultured for up to 8 weeks in chondrogenic differentiation media and harvested at day 1, 28 and 56 for mechanical testing, biochemistry, gene expression, histology and immunohistochemistry for the assessment of cartilage-specific properties. 


\section{Material and Methods}

\section{Isolation of cells}

Primary auricular chondrocytes (AuCHs) and auricular cartilage progenitor cells (AuCPCs) were obtained from deceased equine donors, which were kindly provided by a local slaughterhouse. Bonemarrow-derived MSCs were obtained from healthy equine donors. All tissues and cells were obtained according to the guidelines of the Institutional Animal Ethical Committee (the Netherlands).

$\mathrm{AuCH}$ and AuCPCs were harvested from the auricles of fresh equine cadavers (3- to 10-year-old; $n=3)$. The ears were cut off at the base, shaved, thoroughly washed with soap and soaked for circa 15 min in Betadine ${ }^{\circledR}$ (Meda Pharma, Amstelveen, the Netherlands). Under sterile conditions, an incision through the skin was made on the dorsal side along the longitudinal axis and the skin and subcutaneous tissue were dissected. Ensuring the harvest of auricular cartilage exclusively, the perichondrium was fully removed by carefully scraping the tissue off with surgical tools. Cartilage chips were sectioned off the scapha of the ear, washed in sterile phosphate-buffered saline (PBS) and, subsequently, minced into $1 \mathrm{~mm}^{2}$ pieces. The tissue was digested in $0.2 \%$ pronase (Roche) for $2 \mathrm{~h}$ followed by a $16 \mathrm{~h}$ $0.075 \%$ collagenase type II (Worthington Chemical Corporation, Lakewood, NJ, USA) digestion at $37^{\circ} \mathrm{C}$. Next, the solution was filtered through a $70 \mu \mathrm{m}$ cell strainer and centrifuged for $5 \mathrm{~min}$ at $300 \times g$ to obtain a cell pellet. AuCHs were washed in sterile PBS, counted with a hemocytometer and stored at passage 0 in liquid nitrogen until further use.

For each donor, an aliquot of the freshly-isolated cells was saved for the isolation of AuCPCs, for which the cells were subjected to a fibronectin adhesion assay as previously described (Dowthwaite et al., 2004; Williams et al., 2010). Briefly, cells suspended in serum-free Dulbecco's modified Eagle medium (DMEM; 31966, Gibco) were plated at a density of 500 cells $/ \mathrm{cm}^{2}$ on fibronectin-coated tissue culture plates. After $20 \mathrm{~min}$ of incubation at $37^{\circ} \mathrm{C}$, the nonadherent cells were carefully removed. Attached progenitor cells were cultured in chondroprogenitor expansion media, consisting of DMEM supplemented with $10 \% \mathrm{v} / \mathrm{v}$ fetal bovine serum (FBS; Lonza), $0.2 \mathrm{mM}$ L-ascorbic acid 2-phosphate (Sigma-Aldrich), $100 \mathrm{U} / \mathrm{mL}$ penicillin (Life Technologies), $100 \mu \mathrm{g} / \mathrm{mL}$ streptomycin (Life Technologies) and $5 \mathrm{ng} / \mathrm{mL}$ basic fibroblast growth factor (bFGF; Peprotech, London, UK). After $6 \mathrm{~d}$ of culture, colonies consisting of $>32$ cells were harvested. Monoclonal colonies were pooled and expanded until passage 3, when they were stored in liquid nitrogen until further use.

MSCs were obtained from bone marrow aspirates from the sternum of healthy equine donors (3- to 10-year-old; $n=3$ ) and the mononuclear fraction was isolated following a previously described protocol using a Ficoll ${ }^{\circledR}$-Paque density gradient (GE
Healthcare) (Visser et al., 2014). After isolation, MSCs were cultured in MSC expansion medium, consisting of alpha modification minimum essential medium $(\alpha$ MEM) (22561, Gibco) supplemented with $0.2 \mathrm{mM}$ L-ascorbic acid 2-phosphate (Sigma-Aldrich), $10 \%$ FBS (Lonza), $100 \mathrm{U} / \mathrm{mL}$ penicillin (Life Technologies), $100 \mu \mathrm{g} / \mathrm{mL}$ streptomycin (Life Technologies) and $1 \mathrm{ng} / \mathrm{mL}$ bFGF (Peprotech) until passage 3 and subsequently stored in liquid nitrogen until further use.

\section{Characterization of equine auricular chondroprogenitor cells}

AuCHs (at passage 1), AuCPCs and MSCs (both at passage 3) were characterized by comparison of gene expression of cell surface markers and assessment of multilineage differentiation potential in two dimensional (2D) culture.

The expression of cell membrane markers was evaluated in duplicate by a reverse transcriptasepolymerase chain reaction (RT-PCR), comparing the transcriptome of AuCHs, AuCPCs and MSCs. Analyzed target genes included CD13, CD29, CD31, CD34, CD44, CD45, CD49d, CD73, CD90, CD105, $C D 106, C D 146$ and $C D 166$ (primer sequences and expected amplicon sizes are reported in Table 1), which were compared to expression of the housekeeping gene hypoxanthine phosphoribosyltransferase (HPRT1). RNA was isolated using the RNAeasy mini kit (Qiagen), according to the manufacturer's instructions. Isolated mRNA was quantified by UV-vis spectrophotometry with a Nanodrop 2000 (Thermo Scientific) to serve as template for polymerase chain reaction (PCR). The amplification of RNA was carried out using a SuperScript ${ }^{\circledR}$ OneStep RT-PCR System with Platinum ${ }^{\circledR}$ Taq DNA Polymerase (Life Technologies) and the PCR products were run on agarose gel stained with ethidium bromide. Subsequently, the amplicons were imaged using a UV transilluminator (ProXima 10 Phi; Isogen Life Sciences, De Meern, the Netherlands).

Multipotency was evaluated in duplicate through an in vitro trilineage differentiation assay in which cells were directed towards bone, fat or cartilage by culturing them in osteogenic, adipogenic or chondrogenic differentiation media, respectively. For osteogenic and adipogenic differentiation, cells were plated in 6-well culture plates at a density of $2 \times 10^{5}$ cells/well and cultured in chondroprogenitor expansion medium until sub-confluency, before initiating differentiation. Osteogenic differentiation medium consisted of $\alpha \mathrm{MEM}$ (Gibco) supplemented with $10 \% \mathrm{v} / \mathrm{v}$ FBS (Lonza), $100 \mathrm{U} / \mathrm{mL}$ penicillin (Life Technologies), $100 \mu \mathrm{g} / \mathrm{mL}$ streptomycin (Life Technologies), $0.2 \mathrm{mM}$ L-ascorbic acid 2-phosphate (Sigma-Aldrich), $20 \mathrm{mM} \beta$-glycerol phosphate (Sigma-Aldrich) and $100 \mathrm{nM}$ dexamethasone (Sigma-Aldrich). Adipogenic medium consisted of $\alpha$ MEM (Gibco) supplemented with $10 \%$ v/v FBS (Lonza), $100 \mathrm{U} / \mathrm{mL}$ penicillin (Life Technologies), 
Table 1. RT-PCR forward $(\mathrm{Fw})$ and reverse $(\mathrm{Rv})$ primers sequences used for characterization of $\mathrm{AuCH}$, $\mathrm{AuCPC}$ and MSC.

\begin{tabular}{|c|c|c|}
\hline Target gene & Primer sequence $\left(5^{\prime}\right.$ to $\left.3^{\prime}\right)$ & Amplicon size (bp) \\
\hline \multirow{2}{*}{ HPRT1 } & Fw: CAAGCTTGCTGGTGAAAAG & \multirow{2}{*}{95} \\
\hline & Rv: GGCATATCCTACGACAAACT & \\
\hline \multirow{2}{*}{ CD13 } & Fw: CTGAGTGGAGAGACAGAGTA & \multirow{2}{*}{147} \\
\hline & Rv: CTGGAAATACTCGAAGAGGG & \\
\hline \multirow{2}{*}{ CD29 } & Fw: CTGGAGATGGGAAACTTGG & \multirow{2}{*}{229} \\
\hline & Rv: GTTCCTACTGCTGACTTAGG & \\
\hline \multirow{2}{*}{ CD31 } & Fw: CAGAATCCTTCTCTATGCCC & \multirow{2}{*}{194} \\
\hline & Rv: CATGGCCATCACTGAGTAG & \\
\hline \multirow{2}{*}{ CD34 } & Fw: GACTCAAGGTATCTGCCTG & \multirow{2}{*}{104} \\
\hline & Rv: CCTGTTCTTTCTCACAGAGG & \\
\hline \multirow{2}{*}{ CD44 } & Fw: CTGGGGACTCTGCCTC & \multirow{2}{*}{99} \\
\hline & Rv: TAGCGGCCATTTTTCTCC & \\
\hline \multirow{2}{*}{ CD45 } & Fw: TTGAACGGCCTTGAACC & \multirow{2}{*}{153} \\
\hline & Rv: CTTGGCACCTTCAGTACC & \\
\hline \multirow{2}{*}{ CD49d } & Fw: CTACAACTTGGACACCGAG & \multirow{2}{*}{201} \\
\hline & Rv: GTCCGGTCTGGATTCTTTC & \\
\hline \multirow{2}{*}{ CD73 } & Fw: TCCGGACTTTATTTGCCG & \multirow{2}{*}{346} \\
\hline & Rv: CAGAGGTGACTATGAATGGG & \\
\hline \multirow{2}{*}{ CD90 } & Fw: CTCTACACATGCGAACTCC & \multirow[b]{2}{*}{90} \\
\hline & Rv: CTCGCACTTGACCAGTTT & \\
\hline \multirow{2}{*}{ CD105 } & Fw: CAGTAATGAGGTGGTCGTC & \multirow{2}{*}{108} \\
\hline & Rv: CTGAGGTAGAGGCCCAG & \\
\hline \multirow{2}{*}{ CD106 } & Fw: ACTCTTACTTGTGCACGG & \multirow{2}{*}{103} \\
\hline & Rv: CCACTGAAACTGATCTCTGG & \\
\hline \multirow{2}{*}{ CD146 } & Fw: TCCGTGTGTACAAAGCTC & \multirow{2}{*}{137} \\
\hline & Rv: GTACCAGATGACCTGAGGA & \\
\hline \multirow{2}{*}{ CD166 } & Fw: GTCTTCTGCCTCTTGATCG & \multirow{2}{*}{223} \\
\hline & Rv: CTGTCTTTGTACTCTGGGAC & \\
\hline
\end{tabular}

$100 \mu \mathrm{g} / \mathrm{mL}$ streptomycin (Life Technologies), $0.01 \mathrm{mM}$ Indomethacin (Sigma-Aldrich), $83 \mathrm{mM}$ 3-Isobutyl-1-metylxanthine (Sigma-Aldrich) and $1.72 \mu \mathrm{m}$ bovine pancreas-derived insulin (SigmaAldrich). Culture medium was refreshed every $3 \mathrm{~d}$. For chondrogenic differentiation, $2.5 \times 10^{5}$ cells were pelleted by centrifugation at $300 \times g$ in 15 mL Falcon ${ }^{\circledR}$ tubes. Subsequently, the pellets were cultured in chondrogenic differentiation medium, consisting of DMEM supplemented with $1 \% \mathrm{v} / \mathrm{v}$ insulintransferrin-selenous acid (ITS+ Premix; Corning), $0.2 \mathrm{mM}$ L-ascorbic acid 2-phosphate (Sigma-Aldrich), $100 \mathrm{U} / \mathrm{mL}$ penicillin (Life Technologies), $100 \mathrm{\mu g} /$ $\mathrm{mL}$ streptomycin (Life Technologies), $100 \mathrm{nM}$ dexamethasone (Sigma-Aldrich) and $10 \mathrm{ng} / \mathrm{mL}$ transforming growth factor $\beta 1$ (TGF- $\beta 1$; Peprotech). After $14 \mathrm{~d}$ of culture, osteogenic commitment was evaluated by alizarin red S staining to observe calcified matrix deposition, whereas adipogenic differentiation was assessed with oil red $\mathrm{O}$ staining to visualize the formation of intracellular lipid vesicles. Cell pellets were embedded in paraffin and $5 \mu \mathrm{m}$-thick sections were stained with safranin $\mathrm{O}$ to visualize glycosaminoglycans (GAGs), indicative of chondrogenic differentiation.
Fabrication of cell-laden hydrogel constructs for 3D culture

Following a previously published protocol (Melchels et al., 2014), the hydrogel gelatin methacryloyl (gelMA) was synthesized by functionalizing gelatin type A (obtained from porcine skin; Sigma-Aldrich) in PBS with methacrylic anhydride groups, to obtain a hydrogel with a $80 \%$ degree of functionalization. Subsequently, a $10 \% \mathrm{w} / \mathrm{v}$ solution of gelMA was supplemented with $0.1 \% \mathrm{w} / \mathrm{v}$ 2-hydroxy-1-[4-(2hydroxyethoxy)phenyl]-2-methyl-1-propanone (Irgacure 2959; BASF, Ludwigshafen, Germany) as a photoinitiator. AuCHs, AuCPCs or MSCs, expanded beforehand until passage 1,4 and 4, respectively, were homogeneously suspended in the hydrogel at $37^{\circ} \mathrm{C}$ at a concentration of $1.5 \times 10^{7}$ cells $/ \mathrm{mL}$. The cell-laden gel was immediately casted into a custommade Teflon ${ }^{\mathrm{TM}}$ mold to produce cylindrical samples (diameter $=6 \mathrm{~mm}$, height $=2 \mathrm{~mm}$ ) and subsequently chemically crosslinked by UV irradiation for $5 \mathrm{~min}$ (wavelength $\lambda=365 \mathrm{~nm}$, intensity $\mathrm{E}=3 \mathrm{~mW} / \mathrm{cm}^{2}$, at a height of $2 \mathrm{~cm}$; 144 portable UV lamp, Vilber Lourmat, Eberhardzell, Germany), to trigger freeradical polymerization. Cell-free hydrogel samples (3 replicates per time point) were used as controls 
Table 2. qPCR forward $(\mathrm{Fw})$ and reverse $(\mathrm{Rv})$ primers sequences used for evaluation of cartilage-like tissue synthesis.

\begin{tabular}{|c|c|c|c|}
\hline $\begin{array}{l}\text { Target } \\
\text { gene }\end{array}$ & Full name & Primer sequence ( $5^{\prime}$ to $\left.3^{\prime}\right)$ & $\begin{array}{c}\text { Amplicon size } \\
(\mathrm{bp})\end{array}$ \\
\hline \multirow{2}{*}{ HPRT1 } & \multirow{2}{*}{$\begin{array}{c}\text { Hypoxanthine } \\
\text { phosphoribotransferase } 1\end{array}$} & Fw: AAGCTTGCTGGTGAAAAG & \multirow{2}{*}{95} \\
\hline & & Rv: GCATATCCTACGACAAACT & \\
\hline \multirow{2}{*}{ ACAN } & \multirow{2}{*}{ Aggrecan } & Fw: AAGACAGGGTCTCGCTGCCCAA & \multirow{2}{*}{115} \\
\hline & & Rv: ATGCCGTGCATCACCTCGCA & \\
\hline \multirow{2}{*}{ COL1A1 } & \multirow{2}{*}{ Collagen type I, $\alpha 1$ chain } & Fw: CGTGACCTCAAGATGTGC & \multirow{2}{*}{94} \\
\hline & & Rv: AGAAGACCTTGATGGCGT & \\
\hline \multirow{2}{*}{ COL2A1 } & \multirow{2}{*}{ Collagen type II, $\alpha 1$ chain } & Fw: GGCAATAGCAGGTTCACGTACA & \multirow{2}{*}{79} \\
\hline & & Rv: CGATAACAGTCTTGCCCCACTT & \\
\hline \multirow{2}{*}{ COL10A1 } & \multirow{2}{*}{ Collagen type $X, \alpha 1$ chain } & Fw: GGGAAACGGGATATGGTGCT & \multirow{2}{*}{168} \\
\hline & & Rv: GTCCCCTTTCTCCCGGAATG & \\
\hline \multirow{2}{*}{ COMP } & \multirow{2}{*}{ Cartilage oligomeric protein } & Fw: CCACGTGAATACGGTCACAG & \multirow{2}{*}{104} \\
\hline & & Rv: ACGTCTGCTCCATCTGCTTC & \\
\hline \multirow{2}{*}{ RUNX2 } & \multirow{2}{*}{$\begin{array}{l}\text { Runt-related transcription } \\
\text { factor } 2\end{array}$} & Fw: GCAAGGTTCAACGATCTGA & \multirow{2}{*}{248} \\
\hline & & Rv: GGGACACCTACTCTCATACT & \\
\hline \multirow{2}{*}{ ELASTIN } & \multirow{2}{*}{ Elastin } & Fw: TGGAGTCCCAGGTGTTGTTG & \multirow{2}{*}{137} \\
\hline & & Rv: CATAGCCAGGAACCCCGAA & \\
\hline
\end{tabular}

and were prepared following the same steps. All hydrogel samples were cultured in chondrogenic differentiation medium for 1,28 and $56 \mathrm{~d}$ at $37^{\circ} \mathrm{C}$ and $5 \% \mathrm{CO}_{2}$, refreshing media 3 times per week.

\section{Gene expression of cartilage markers after chondrogenic differentiation}

The relative gene expression of cartilage markers in cell-laden hydrogels $(n=3)$ was evaluated by qPCR at 1 and $56 \mathrm{~d}$ of culture. Analyzed markers included aggrecan $(A C A N)$, cartilage oligomeric matrix protein $(C O M P)$, collagen type II (COL2A2), collagen type I (COL1A1), collagen type X (COLXA1), runtrelated transcription factor 2 (RUNX2) and elastin. The expression levels were normalized against the housekeeping gene HPRT1. Primer sequences for each transcript are reported in Table 2.

Gel samples were mechanically ground in RLT buffer (Qiagen). From the lysate, mRNA was isolated using the RNeasy Mini Kit (Qiagen) and subsequently quantified with a Nanodrop 2000 (Thermo Scientific). A SuperScript ${ }^{\circledR}$ III Platinum SYBR Green One-Step qRT-PCR Kit (Life Technologies) was used for amplification of the mRNA and cDNA synthesis, which was performed with a LightCycler ${ }^{\circledR} 96$ (Roche). The PCRminer algorithm (Zhao and Fernald, 2005) was used to calculate relative gene expression, $\mathrm{Ct}$ and efficiency values.

\section{Biochemical analysis of cell-laden hydrogels}

After 1, 28 and $56 \mathrm{~d}$ in culture, 4-6 replicates of each group of cell-laden hydrogels were taken for quantification of DNA and GAG content. Cellladen hydrogel samples were frozen at $-20{ }^{\circ} \mathrm{C}$ and subsequently lyophilized. The wet and dry weights were recorded during this process. Digestion of samples occurred overnight at $60{ }^{\circ} \mathrm{C}$ in $200 \mu \mathrm{L}$ papain digestion buffer (P3125; Sigma Aldrich), consisting of $0.2 \mathrm{M} \mathrm{NaH}_{2} \mathrm{PO}_{4}$ (Merck) and 0.01 $\mathrm{M}$ ethylenediaminetetraacetic acid (EDTA; VWR) in milliQ water $(\mathrm{pH}=6.0)$ supplemented with $250 \mu \mathrm{L} /$ $\mathrm{mL}$ papain solution (16-40 units/mg of protein) and 0.01 M cysteine (C9768; Sigma Aldrich).

Total DNA content was quantified using a QuantiT PicoGreen dsDNA assay (Life Technologies) and compared to a standard of known concentrations of DNA. The fluorescence was measured at $485 \mathrm{~nm}$ excitation and $520 \mathrm{~nm}$ emission by a spectrofluorometer (Bio-Rad).

Total GAG content, as a measure of cartilagespecific matrix production, was quantified using a dimethylmethyleneblue (DMMB; $\mathrm{pH}=3.0)$ assay. The $525 / 595 \mathrm{~nm}$ absorbance ratio was measured with a VersaMax plate reader (Molecular Devices, Winnersh, UK). The sulfated GAG (sGAG) content was calculated using a standard of known concentrations of chondroitin sulfate $\mathrm{C}$ and corrected for the dilution factor.

Both dsDNA and sGAG content were normalized against dry weight. The ratio of GAGs per DNA was calculated to display the activity of single cells in producing cartilage-specific matrix.

\section{Compressive mechanical testing of hydrogel constructs}

An unconfined uniaxial compression test was performed to evaluate the mechanical properties of the cell-laden hydrogel samples after 1, 28 and $56 \mathrm{~d}$ in culture (4-6 replicates per time point). Using a dynamic mechanical analyzer (DMA Q800; TA Instruments, Asse, Belgium), samples were compressed at a $-20 \% / \mathrm{min}$ strain rate to $-30 \%$. Young's modulus was calculated as the slope of the initial linear segment (10-15\% strain) of the stress/ strain curve. 


\section{Histology and immunohistochemistry}

Deposition of the main components of cartilage extracellular matrix in cell-laden hydrogels were visualized by histology and immunohistochemistry on formalin-fixed, paraffin-embedded samples.

After 1, 28 and $56 \mathrm{~d}$ in culture, samples from each group were fixated in $4 \%$ neutral-buffered formalin. Then, they were dehydrated through a graded ethanol series (70\%, $96 \%$ and $100 \%$ ethanol), cleared in xylene and embedded in paraffin. The samples were sectioned into $5 \mu \mathrm{m}$-thick slices and deparaffinized prior to staining. For the identification of cartilage glycosaminoglycan deposition, a triple stain, consisting of hematoxylin (cell nuclei), fast green (collagens) and safranin $\mathrm{O}$ (proteoglycans), was applied. Deposition of collagens was evaluated by immunohistochemistry, with appropriate primary antibodies for collagen type II (II-II6B3; DSHB, Iowa City, IA, USA), collagen type I (sc-8784; Santa Cruz Biotechnology) and collagen type VI (5C6; DSHB). In addition, appropriate IgG were used as isotype controls. After deparaffinization, samples were treated with $0.3 \% \mathrm{v} / \mathrm{v}_{2} \mathrm{O}_{2}$ to block endogenous peroxidases. Antigen retrieval was performed with $1 \mathrm{mg} / \mathrm{mL}$ pronase (Roche) and $10 \mathrm{mg} / \mathrm{mL}$ hyaluronidase (H2126; Sigma-Aldrich), both applied for $30 \mathrm{~min}$ at $37^{\circ} \mathrm{C}$. Subsequently, tissue sections were blocked with bovine serum albumin (BSA, $5 \% \mathrm{w} / \mathrm{v}$ in PBS) for $1 \mathrm{~h}$ at room temperature. The primary antibodies were incubated overnight at $4{ }^{\circ} \mathrm{C}$, followed by a HRP-tagged secondary antibody for $1 \mathrm{~h}$ at room temperature, after which the staining was developed with 3,3-diaminobenzidine-horseradish peroxidase (Sigma-Aldrich). Cell nuclei were counterstained with hematoxylin. A von Kossa staining was applied to detect calcium precipitates indicating tissue mineralization. All stained sections were mounted in DPX mounting media (Millipore) and examined using a light microscope (Olympus BX51; Olympus).

\section{Statistical analysis}

Quantitative results are expressed as mean \pm standard error of the mean (SEM). The means of the experimental groups were compared at different time points by performing a two-way ANOVA with a Bonferroni post-hoc test. The statistical analyses were performed using Graphpad Prism 7 (Graphpad software). A value of $p<0.05$ was considered statistically significant.

\section{Results}

Equine auricular cartilage progenitor cells displayed stem cell qualities

Histological evaluation confirmed that the perichondrial layer attached to auricular cartilage was successfully removed and, therefore, it was assumed that a population of exclusively cartilagederived cells was obtained after tissue digestion, prior to isolation of cartilage progenitor cells using differential adhesion to fibronectin (Fig. 1).

Gene expression of several surface markers was analyzed for isolated AuCHs, AuCPCs and MSCs by RT-PCR (Fig. 2a), demonstrating that the transcript profile of AuCPCs shared similarities with both $\mathrm{AuCH}$ and MSCs. Like MSCs, AuCPCs were positive for the stem cell markers CD73, CD90 and CD105 and negative for the hematopoietic marker CD34 and for the leukocyte marker $C D 45$. Thus, at the transcript level, AuCPCs satisfied the minimal requirements to be classified as human MSCs (Dominici et al., 2006). Furthermore, all three cell types were $C D 29^{+}$, $C D 31^{+}, C D 106^{+}$and $C D 166^{+}$. Differences among cell types arose in the expression of $C D 13, C D 49 d$ and CD146. CD13 was highly positive in AuCPCs, to a lesser extent in MSCs and negative in AuCHs. CD49d appeared positive in MSCs and AuCPCs and negative in AuCHs. Lastly, CD146 was faintly positive in both MSCs and AuCPCs and negative in AuCHs.

Multipotency of AuCPCs was assessed through a trilineage differentiation assay. Like MSCs (Fig. $2 \mathbf{c}, \mathbf{e}, \mathbf{f}), \mathrm{AuCPCs}$ demonstrated to be capable of differentiating towards bone (Fig. 2b), adipose tissue (Fig. 2d) and cartilage (Fig. 2f), confirming their multipotent potential.

\section{Differential mRNA expression of cartilage \\ markers in hydrogel culture}

As measured by qPCR, AuCHs, AuCPCs and MSCs embedded in 3D hydrogels exhibited increased relative-fold expression levels of cartilage-specific

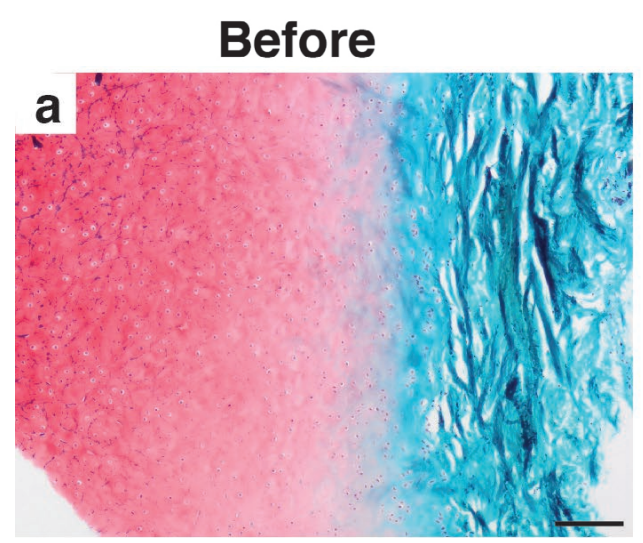

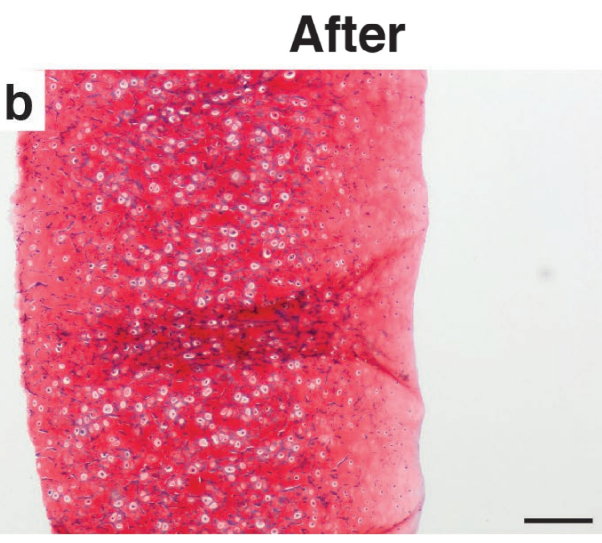

137
Fig. 1.Safranin Ostaining (a) before and (b) after utilizing the scraping method for the removal of perichondrium, confirming its complete removal from the auricular cartilage. Scale bars: $200 \mu \mathrm{m}$. 
gene transcripts over time, confirming their differentiation in the hydrogel (Fig. 3).

After $56 \mathrm{~d}$ of culture, aggrecan expression (Fig. 3a) was highest in AuCHs (48.8-fold upregulation), followed by AuCPCs (37.7-fold) and MSCs (15.7-fold). The same correlation was already apparent at day 1: mRNA expression of aggrecan was significantly more upregulated in AuCHs and AuCPCs (10.8- and 8.6-fold, respectively) than MSCs, expressing a 0.1fold reduction. The expression of aggrecan increased over time in all three cell types, yet this increase was significant only in AuCHs.

A similar pattern was observed for the mRNA expression of COMP (Fig. 3b), which is a prominent non-collagenous matrix protein present in cartilage (Hedbom et al., 1992; DiCesare et al., 1995; Newton et al., 1994). After $56 \mathrm{~d}$ of culture, AuCPCs exhibited a significantly higher expression level of COMP than MSCs (186.2-fold versus 64.2-fold, respectively), with AuCHs displaying a 146.7-fold increment. Likewise, AuCPCs already demonstrated the highest upregulation of COMP (39.1-fold) at day 1, followed by AuCHs (20.5-fold) and MSCs (0.9-fold). Both $\mathrm{AuCH}$ and $\mathrm{AuCPC}$ displayed a significant increase in expression levels over time, whereas MSCs did not.

After $56 \mathrm{~d}$ of culture, AuCHs and AuCPCs expressed COL2A1 (Fig. 3c) at comparable levels, with a 51- and 60-fold increment, respectively. MSCs exhibited the highest levels of COL2A1 mRNA with an 89.1-fold increment at day 56, yet this difference was not significant. Expression of COL2A1 was considerably lower ( $<3.5$-fold) in all three cell types at the beginning of the culture, indicating a significant increase over time in the case of AuCPCs and MSCs. Conversely, COL1A1 (Fig. 3d) was already highly upregulated at the beginning of the culture in MSCs (59.9-fold increment), compared to a significantly lower 19.3-fold in $\mathrm{AuCH}$ and 22.8-fold in AuCPCs. This trend reversed during chondrogenic differentiation, as in AuCHs, the expression of COL1A1 significantly increased over time. Differences among cell types were not significant at day 56, yet the highest expression at day 56 was measured in AuCHs (77.2-fold increment), followed by equivalent levels in AuCPCs and MSCs (54.2- and 48.1-fold, respectively). AuCHs exhibited significantly higher levels of COL10A1 at the end of culture (3-fold) in comparison to both AuCPCs and MSCs, which exhibited a 0.4-fold lesser expression (Fig. 3e). Both AuCHs and MSCs showed increasing yet non-significant levels of COL10A1, whereas, in AuCPCs, COL10A1 expression levels decreased nonsignificantly over time.

At day 56, the expression of RUNX2 (Fig. 3f), the master transcription factor during osteogenesis and endochondral ossification, was significantly higher in
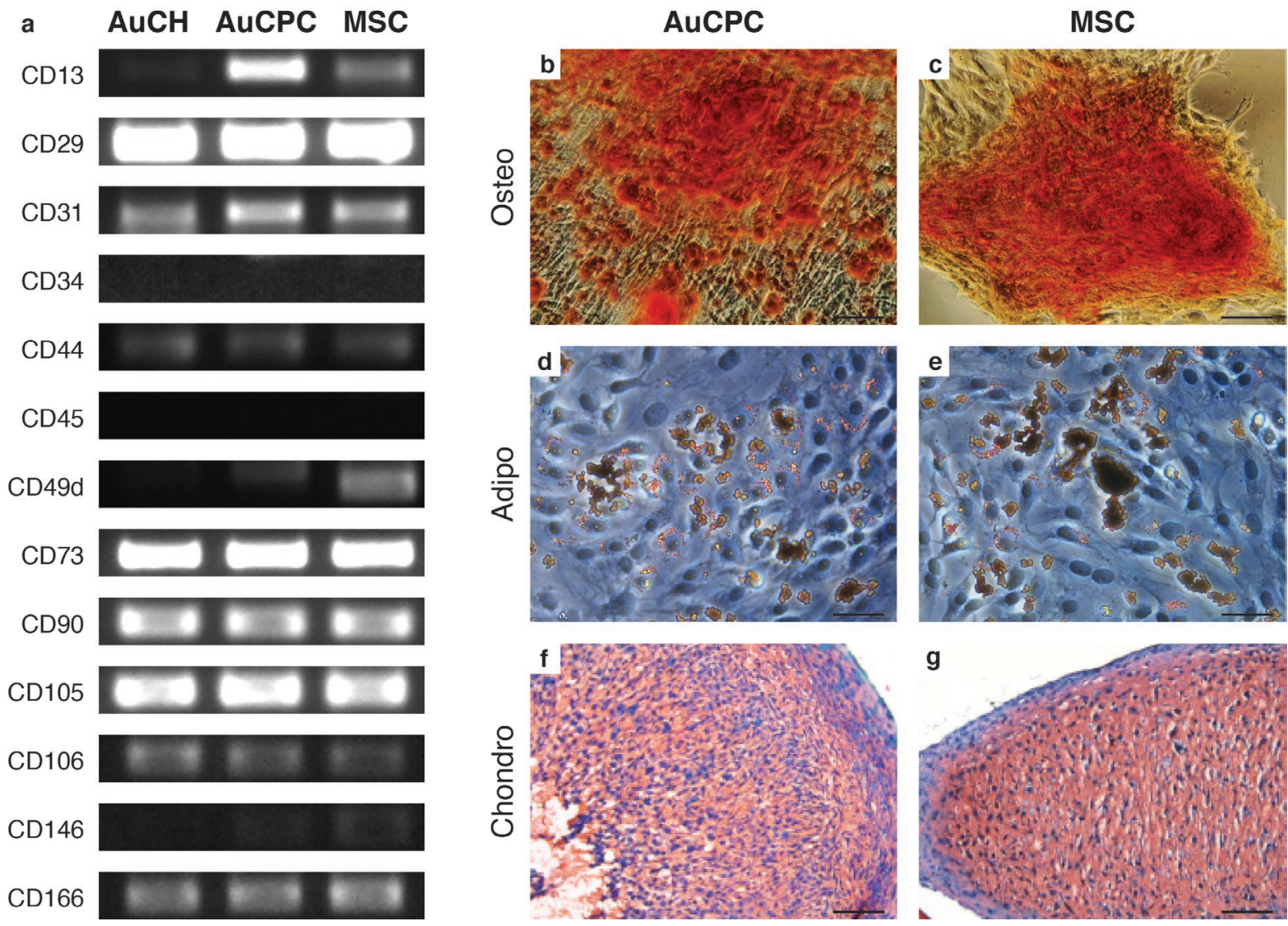

Fig. 2. Characterization of AuCPCs in comparison to AuCHs and MSCs. (a) The expression of several surface markers, analyzed by RT-PCR, was compared amongst the three cell types. Trilineage differentiation of AuCPCs and MSCs: $(\mathbf{b}, \mathbf{c})$ alizarin red staining demonstrating osteogenic differentiation, (d,e) oil red $\mathrm{O}$ staining demonstrating adipogenic differentiation and $(\mathbf{f}, \mathbf{g})$ safranin $\mathrm{O}$ staining demonstrating chondrogenic differentiation. Scale bars: $100 \mu \mathrm{m}$. 
MSCs (2.5-fold) as compared to AuCHs (0.3-fold) and AuCPCs (0.0-fold). At the start of the culture, RUNX2 was upregulated by 1.1-fold in AuCHs, by 1.9-fold in AuCPCs and by 2.1-fold in MSCs. AuCPCs showed a significant decrease in RUNX2 expression over time to virtually zero at day 56 .

a

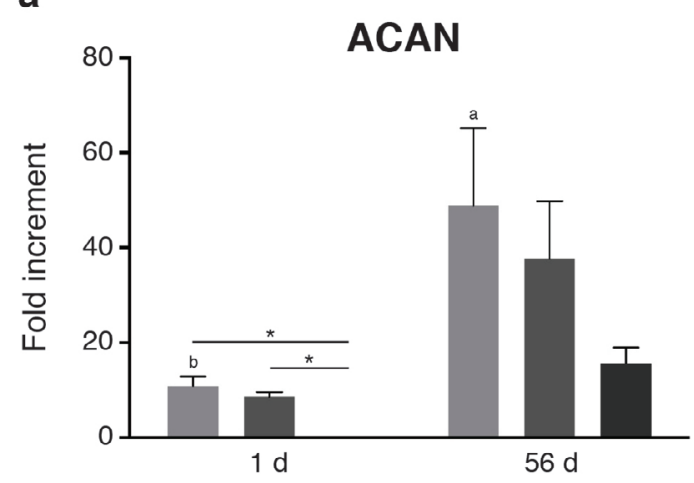

C

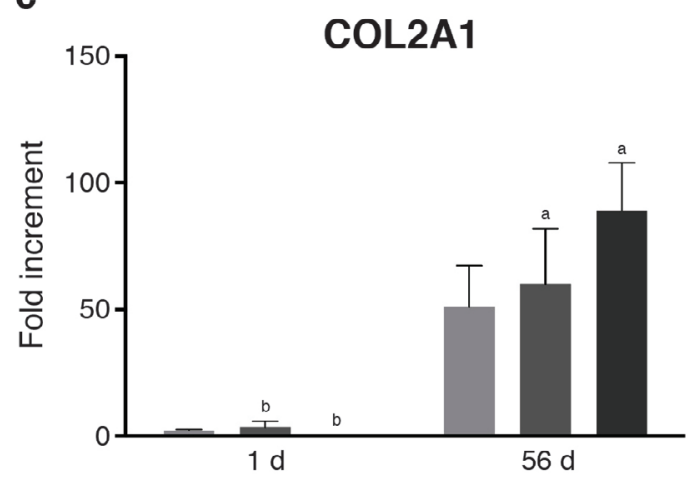

e

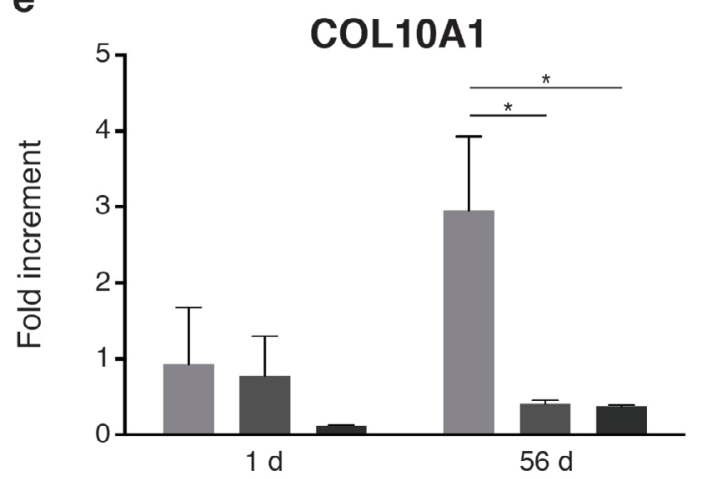

9

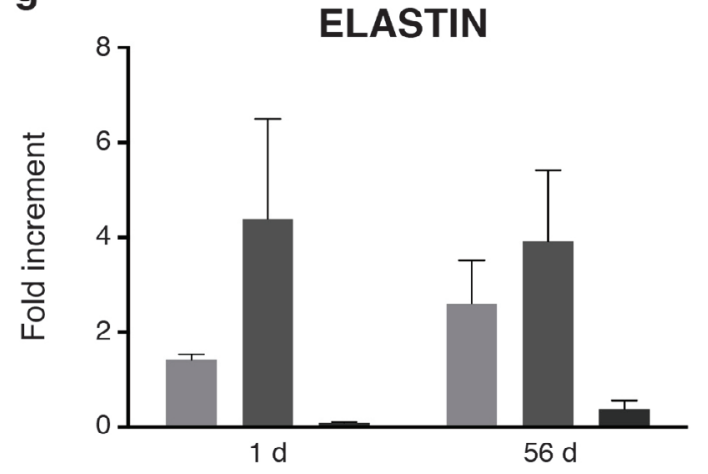

The critical structural component of elastic cartilage is elastin. AuCHs exhibited higher mRNA expression levels of elastin (1.4-fold at day 1 and 2.6-fold at day 56) than MSCs (0.1-fold at day 1 and 0.4-fold at day 56). Although not significant, AuCPCs showed the highest upregulation of elastin, with

b

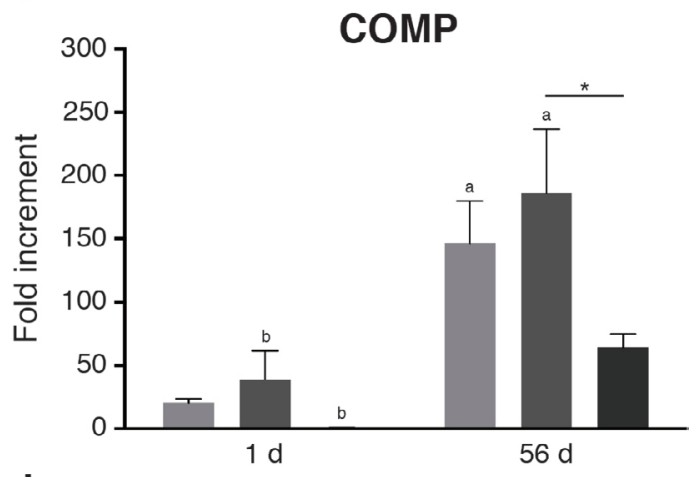

d

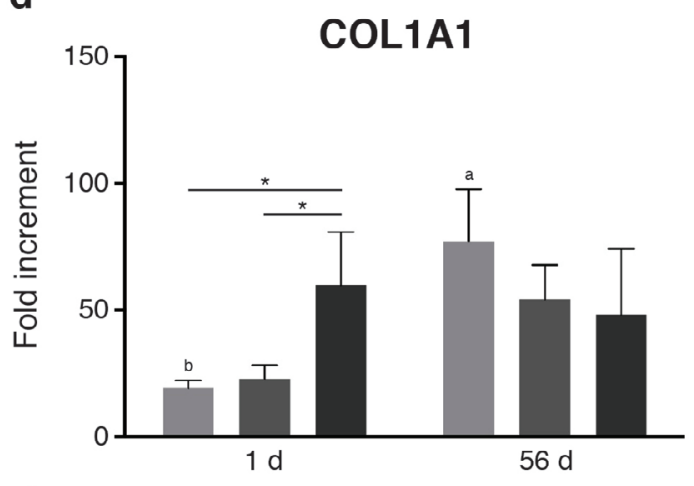

f

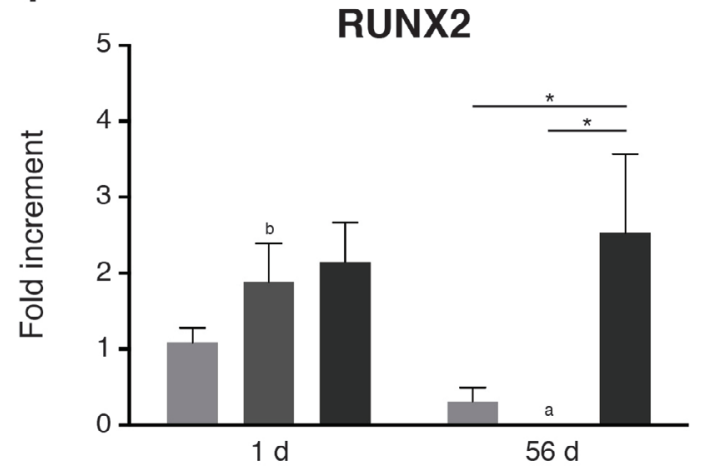

Fig. 3. Relative gene expression of (a) collagen type II, (b)collagen type I, (c) collagen type X, (d) aggrecan, (e) cartilage oligomeric matrix protein, (f) RUNX2 and (g) elastin, as obtained from qPCR analysis of cell-laden hydrogels. Statistically significant differences of $p<0.05$ for comparisons between cell types are marked with *. For each cell type, statistically significant differences of $p<0.05$ are marked with a for a significant difference to day 1 and $^{\mathrm{b}}$ for a significant difference to day 56. 
4.4-fold and 3.9-fold increments at day 1 and 56, respectively (Fig. 3g).

\section{Chondrogenic differentiation in hydrogels} resulted in cartilage-specific matrix deposition Cell proliferation and extracellular matrix deposition in cell-laden hydrogels was assessed by quantification of dsDNA and sGAG content, representative of cell number and proteoglycan quantity, respectively. As indicated by the increase in dsDNA content in the first $28 \mathrm{~d}$ of culture, AuCPCs and MSCs showed an ability to proliferate in the 3D gelMA hydrogel environment. The dsDNA content of $\mathrm{AuCHs}$ was significantly higher than AuCPCs and MSCs in the beginning of the culture period and stayed stable during the first $28 \mathrm{~d}$; then, it significantly decreased to levels comparable to the other two cell types. These differences in cell numbers among groups at the beginning of culture could possibly be attributed to cell-loading inconsistencies. Nevertheless, dsDNA content among groups appeared to equalize over time (Fig. 4a).

The synthesis of neocartilage matrix was evaluated by the amount of sulfated GAGs present in the hydrogel samples. Over the course of chondrogenic culture, AuCHs, AuCPCs and MSCs produced significantly increasing amounts of sGAG, which were retained in the hydrogel matrix. $\mathrm{AuCHs}$ and

a

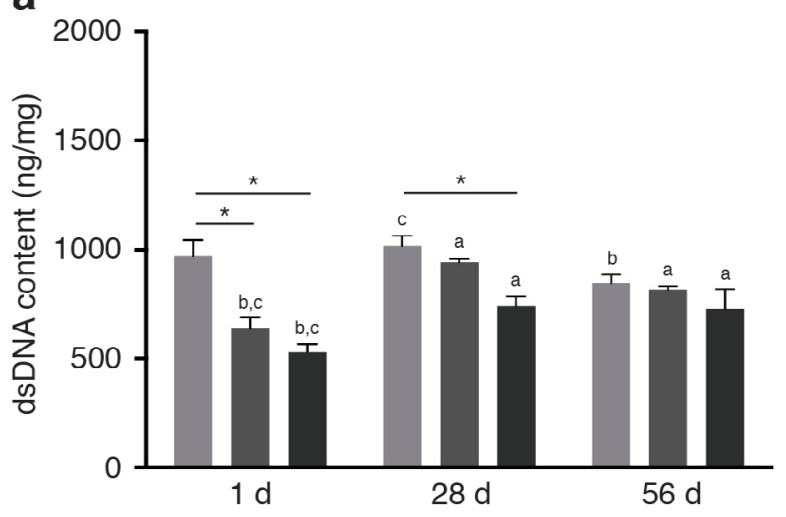

C

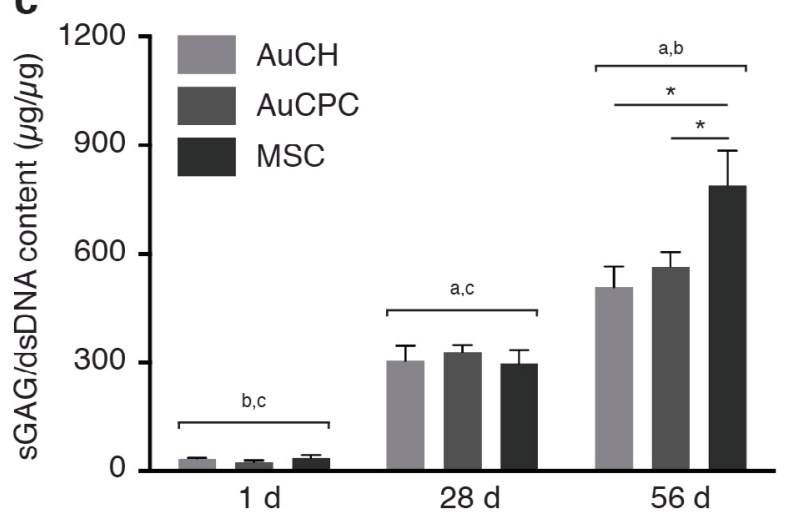

AuCPCs showed similar trends in total sGAG content (Fig. $4 \mathbf{b}$ ) as well as in sGAG normalized to dsDNA content (Fig. 4c). After $56 \mathrm{~d}$ of culture, total sGAG content in AuCHs was $409.9 \pm 35.7 \mu \mathrm{g} /$ $\mathrm{mg}$ and in AuCPCs $458.4 \pm 30.9 \mu \mathrm{g} / \mathrm{mg}$; sGAG/ dsDNA was $509.9 \pm 56.8 \mu \mathrm{g} / \mathrm{mg}$ and $565.2 \pm 40.8 \mu \mathrm{g} /$ $\mathrm{mg}$, respectively. MSCs initially appeared to lag behind in total sGAG content $(214.5 \pm 25.1 \mu \mathrm{g} /$ $\mathrm{mg}$ at day 28 , compared to $292.7 \pm 29.5 \mu \mathrm{g} / \mathrm{mg}$ for $\mathrm{AuCHs}$ and $308.3 \pm 15.8 \mu \mathrm{g} / \mathrm{mg}$ for AuCPCs), yet encompassed lower cell numbers in the samples. Accordingly, when normalized to dsDNA content, $\mathrm{AuCHs}, \mathrm{AuCPCs}$ and MSCs performed similarly at the 28 -d time point $(304.9 \pm 42.6,329.7 \pm 19.9$ and $296.9 \pm 38.1 \mu \mathrm{g} / \mathrm{mg}$, respectively). However, after $56 \mathrm{~d}$ of culture, when dsDNA levels were equivalent among groups, MSCs $(789.5 \pm 95.4 \mu \mathrm{g} / \mathrm{mg})$ significantly outperformed both cartilage-derived cell types, displaying sGAG/dsDNA values 1.6-fold higher than AuCHs $(508.9 \pm 56.8 \mu \mathrm{g} / \mathrm{mg})$ and 1.4-fold higher than AuCPCs (565.2 $\pm 40.8 \mu \mathrm{g} / \mathrm{mg})$.

\section{Mechanical properties of cell-laden hydrogels increased over time}

Compressive mechanical testing was performed to evaluate the progressive changes in the stiffness of the constructs over time (Fig. 5). After $28 \mathrm{~d}$ of chondrogenic culture, the compressive Young's

b

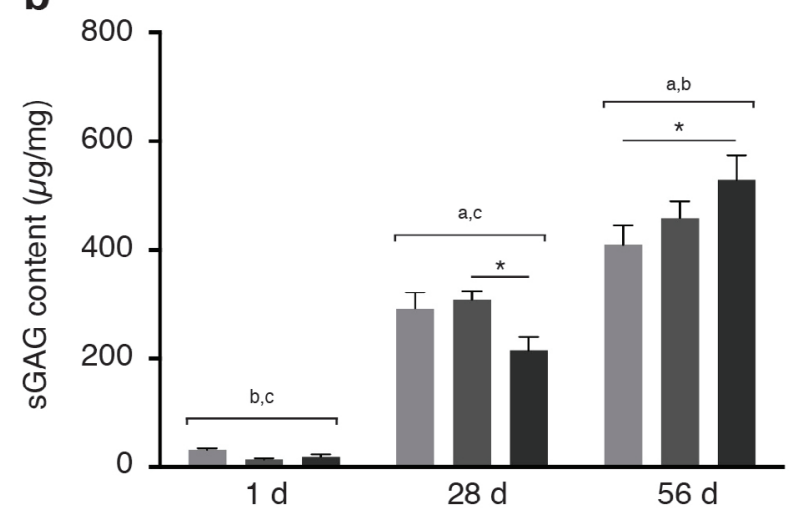

Fig. 4. Quantification of (a) sulfated GAG content and (b) dsDNA content in cell-laden hydrogels after 28 and $56 \mathrm{~d}$ of chondrogenic culture, both normalized against dry weight. The sGAG per dsDNA ratio is shown in c.Statistically significant differences of $p<0.05$ for comparisons between cell types are marked with *. For each cell type, statistically significant differences of $p<0.05$ are marked with a for a significant difference to day 1 and ${ }^{b}$ for a significant difference to day 56. 


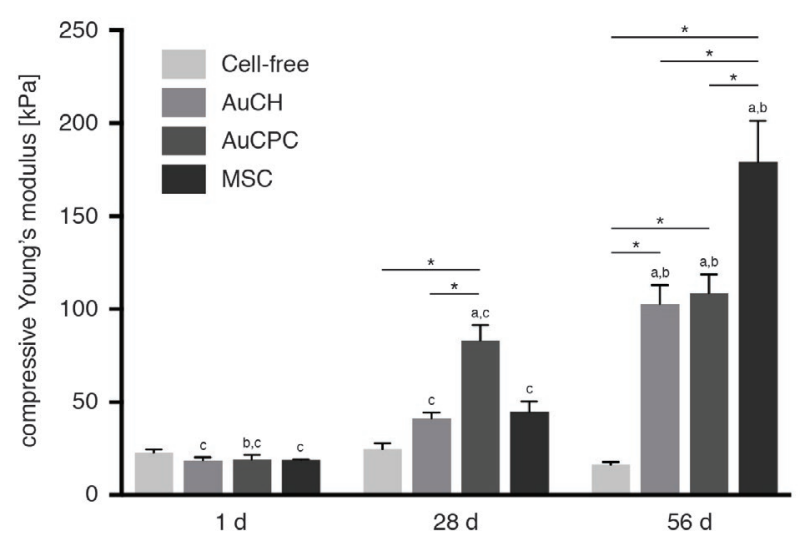

Fig. 5. Compressive Young's modulus of cell-laden hydrogels after 28 and $56 \mathrm{~d}$ of culture as compared to cell-free samples. Statistically significant differences of $p<0.05$ for comparisons between cell types are marked with *. For each cell type, statistically significant differences of $p<0.05$ are marked with a for a significant difference to day 1 and $^{\mathrm{b}}$ for a significant difference to day 56 .

modulus of AuCHs $(41.3 \pm 3.0 \mathrm{kPa})$ and MSCs $(44.9 \pm 5.6 \mathrm{kPa})$ increased non-significantly of 1.6 -fold and 1.8-fold, respectively, in comparison to cell-free samples. Both cell types were outperformed by AuCPCs $(83.2 \pm 8.1 \mathrm{kPa})$, which exhibited a significant 3.3-fold increase. When comparing these results to the total sGAG contents per sample, a 1.4-fold difference between AuCPCs and MSCs was noted; however, the observed difference in mechanical properties between AuCPCs and AuCHs was not reflected in total sGAG content.

At the end of the culture period, MSCs $(179.2 \pm 22.2 \mathrm{kPa})$ significantly outperformed both $\mathrm{AuCHs}(102.8 \pm 10.2 \mathrm{kPa})$ and AuCPCs $(108.6 \pm 10.1 \mathrm{kPa})$ in terms of compressive Young's modulus (1.7-fold and 1.6-fold difference, respectively), correlating with the observed trends in total sGAG and sGAG/dsDNA content. In comparison with cell-free hydrogels, cellladen constructs demonstrated a significant increase in the compressive modulus of 10.5-fold for MSCs, 6.4-fold for AuCPCs and 6.1-fold for AuCHs.

The compressive Young's modulus of cell-free constructs remained in the range of $16-25 \mathrm{kPa}$ at all time points, indicating no notable degradation of the bulk properties of the hydrogel during the period of in vitro culture. In general, cartilage matrix synthesis in cell-laden hydrogels, as indicated by the total sGAG content, correlated with an increase in mechanical properties of the samples.

\section{Histology and immunohistochemistry confirm matrix deposition}

Histological sections displayed the presence and distribution of several main components of cartilage extracellular matrix in the hydrogel, including proteoglycans as well as collagen type II, I and VI (Fig. 6).

AuCHs, AuCPCs and MSCs showed inhomogeneous distribution of synthesized proteoglycans throughout the hydrogel constructs (Fig. 6a-c), with a gradation of decreasing labeling from the pericellular territorial to inter-territorial matrices. In all cases, there was an evident increase in the intensity of safranin $\mathrm{O}$ staining for proteoglycans over time. In line with the trends in total sGAG content, MSCs qualitatively displayed less proteoglycans at $28 \mathrm{~d}$ of culture, yet exhibited the most intense staining at the end of the culture period in comparison to $\mathrm{AuCPC}$ and to a greater extent to AuCHs. In all experimental groups, the deposition of collagen type II and type I seemed to occur predominantly in the outer rim of the cylindrical hydrogel constructs, with a lighter staining in the center. The diameter of this outer rim appeared to widen over time, indicating increased matrix deposition towards the center of the construct. MSCs and AuCPCs exhibited a more homogeneous distribution of collagen type II, whereas AuCHs displayed clusters of intense pericellular labeling (Fig. 6d-f). A similar trend was noted for collagen type I (Fig. 6g-i), where rims with the highest intensity staining were found in $\mathrm{AuCH}$ samples, followed by MSCs and AuCPCs. These observations correlated with COL1A1 mRNA expression profiles at day 56. Collagen type VI-labelled clusters (Fig. 6j1) were observed pericellularly after $56 \mathrm{~d}$ of culture in AuCPCs and to a lesser extent in MSCs, with only sporadic staining in AuCHs. Finally, von Kossa staining for mineralization did not show any black staining indicative of calcium in either group (Fig. 6m-o).

\section{Discussion}

Cell selection for the generation of clinically relevantsize cartilage tissue constructs remains a notable challenge in tissue engineering strategies. Cartilagederived progenitor cells represent a promising cell source for use in tissue engineering-based clinical therapies, since they can generate large numbers of cells while maintaining chondrogenic differentiation potential (Williams et al., 2010). In this study, progenitor cells originating from auricular cartilage demonstrated cartilage formation capacity in a 3D hydrogel system by generating a cartilage-like matrix in vitro.

Traditionally, chondrocytes from various cartilage tissues (auricular, articular, costal and nasoseptal) are predominantly used for the engineering of auricular structures. Autologous cells have the greatest clinical potential in view of infectious considerations and adverse immunological response (Saadeh et al., 1999). Nevertheless, the acquisition of a sufficient number of cells remains an important limitation in current tissue engineering approaches, since extensive expansion is required to obtain sufficient numbers of autologous cells for the creation of a large tissue constructs (Bichara et al., 2012). After only few population doublings in vitro, auricular, articular, septal and costal chondrocytes undergo 
dedifferentiation and lose their capacity to produce cartilage-specific glycosaminoglycans and collagens (Chung et al., 2006; Schulze-Tanzil et al., 2004; Schnabel et al., 2002; Homicz et al., 2002; Lee et al., 2007; Nabzdyk et al., 2009; Williams et al., 2010). Although some studies demonstrate cartilagelike tissue formation using extensively expanded chondrocytes, these dedifferentiated cells required the addition of fresh chondrocytes in order to salvage some of the chondrogenic phenotype characteristics (Pomerantseva et al., 2016; Tseng et al., 2014). Hence, primary chondrocytes seem less suitable as a single donor source for cartilage tissue engineering of large constructs, yet they may be beneficial additions to cocultures (Kang et al., 2012; Lv et al., 2012; Pleumeekers et al., 2015).

MSCs are also successfully applied for the generation of cartilage-like tissue constructs (Cheng et al., 2014; Pleumeekers et al., 2013; Seda Tigli et al., 2009; Vinardell et al., 2012). MSCs are attractive for cartilage tissue engineering as they are harvested from the bone marrow with minimally invasive procedures, can be expanded to yield high cell numbers without losing their tissue-specific phenotype (Gardner et al., 2013) and have multipotent differentiation ability (Pittenger et al., 1999). In 3D culture, MSCs can be directed towards the chondrogenic lineage and are consequently applied in numerous studies for the generation of cartilage (Cheng et al., 2014; Pleumeekers et al., 2013; Seda Tigli et al., 2009; Vinardell et al., 2012). In fact, their usage is already being explored in clinical trials such as NCT02037204 (IMPACT), NCT00885729 and NCT01227694 (as registered on clinicaltrials.gov). Nevertheless, the usage of MSCs for cartilage engineering harbors the risk of terminal differentiation of cells and subsequent calcification and ossification of tissues (Williams et al., 2010). This results in calcification of the extracellular matrix (Gawlitta et al., 2010) - a phenomenon that is also observed in the costal cartilage framework implanted during auricular reconstruction surgery causing an increasingly rigid construct (Jessop et al., 2016). This is an unfavorable outcome for engineered auricular tissue structures as elasticity is one of the key features of the external ear (Nimeskern et al., 2015b; Pappa et al., 2013; Xu et al., 2005).

Tissue-specific progenitor cells maintain stemcell-like proliferative potential, yet also display tissue-specific phenotypes since they are harvested directly from the target tissue. In vivo, environmental influences from their niche prime progenitors to regulate proliferation and differentiation towards the target tissue, providing a clear advantage over non-tissue-specific stem-cells-like MSCs. Their proliferative ability addresses the important limitation in cell number acquisition that continues
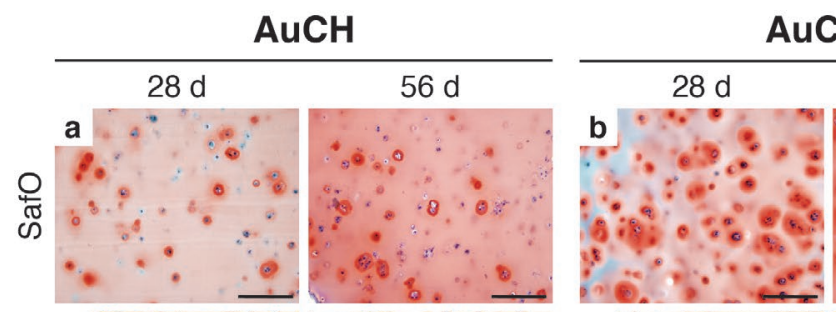

AuCPC
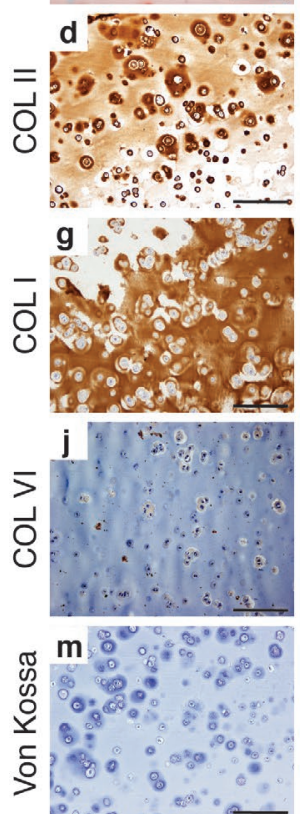
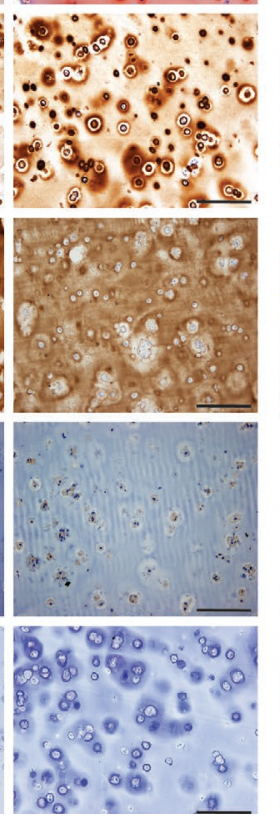
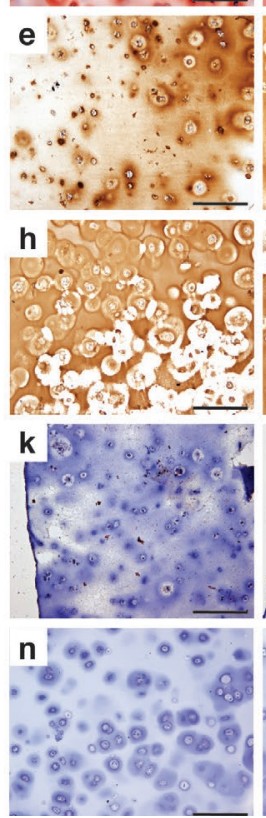

56
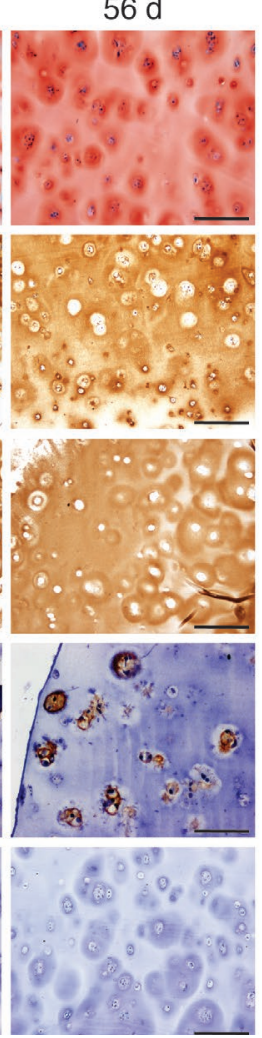

MSC
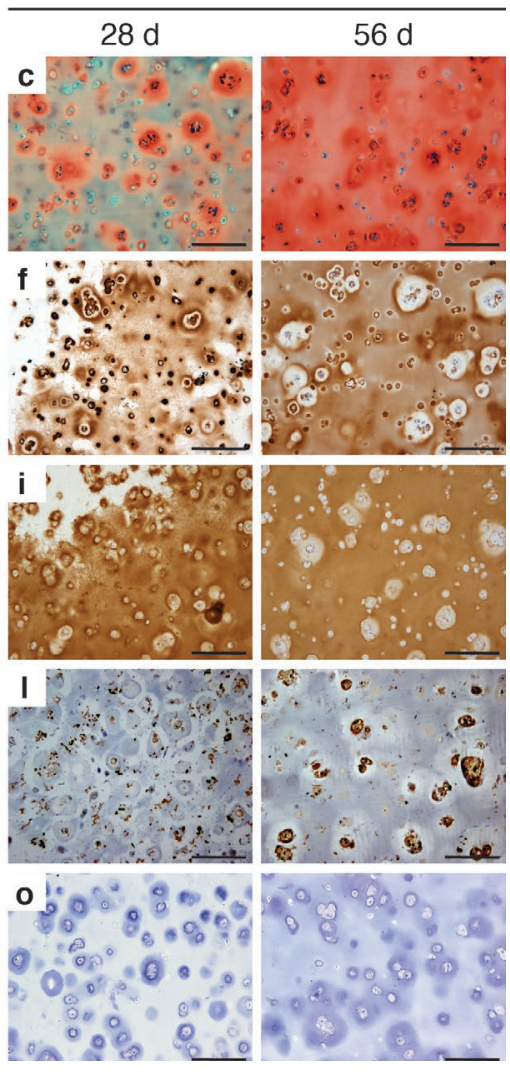

Fig. 6. Histological analysis of cell-laden hydrogels after 28 and $56 \mathrm{~d}$ in chondrogenic culture. Safranin $\mathrm{O}$ staining visualizing proteoglycan deposition in $(\mathbf{a}) \mathrm{AuCH},(\mathbf{b}) \mathrm{AuCPC}$ (c) and MSC samples, as well as immunohistochemistry for $(\mathbf{d}, \mathbf{e}, \mathbf{f})$ collagen type II, $(\mathbf{g}, \mathbf{h}, \mathbf{i})$ collagen type I and $(\mathbf{j}, \mathbf{k}, \mathbf{l})$ collagen type VI. (m,n,o) Von Kossa staining demonstrating the absence of mineralization in all three cell types. Scale bars: $150 \mu \mathrm{m}$. 
to hamper the translation of large tissue-engineered constructs to clinical application. Cartilage stem/ progenitor cells were first identified in the superficial zone of the articular cartilage of the knee (Dowthwaite et al., 2004); yet, conclusive definitions on the identity of these cells remain elusive (Jiang and Tuan, 2015). Nevertheless, it is clear that cartilage tissue harbors a potent subpopulation of cells with distinct abilities from primary chondrocytes and a similar nature to MSCs. The current work presented the first identification and evaluation of this subpopulation of progenitor cells in equine auricular cartilage tissue and their potential for cartilage tissue engineering approaches.

Previous literature reporting progenitor cells from auricular tissue is principally focused on cells originating from the perichondrial layer (Kobayashi et al., 2011a; Kobayashi et al., 2011b; Togo et al., 2006), which is a fibrous connective tissue consisting of fibroblasts and perichondrocytes. Recently, the first demonstration of the presence of an auricular cartilage progenitor population separated from the perichondrium has been presented by Xue $\mathrm{et}$ al. (2016) in a porcine species. The proliferation rate of these auricular cartilage stem/progenitor cells (CSPCs) is comparable to bone marrow-derived MSCs (Xue et al., 2016). Although the authors report a higher proliferation rate for perichondrium stem/progenitor cells (PSPCs), chondrogenic differentiation potential is greater for auricular cartilage stem/progenitor cells (Xue et al., 2016). PSPCs can differentiate into chondrocytes, yet maintaining a fibroblastic morphology (Kobayashi et al., 2011a; Xue et al., 2016). Cells derived from the cartilage tissue appear more apt to differentiate towards the chondrogenic and osteogenic lineages, whereas perichondrium-derived progenitor cells are inclined towards adipogenic differentiation (Xue et al., 2016). The cartilageforming potential of cartilage stem/progenitor cells has not yet been explored in 3D biomaterial culture for tissue engineering purposes. Hence, the present study focused on the use of cartilage progenitor cells, derived from the cartilage after complete removal of the perichondrium, for elastic cartilage tissue engineering. Besides fundamental characterization of these putative cartilage progenitor cells, their potential for cartilage regeneration for future therapeutic applications is of major interest.

The results from the characterization of AuCPCs demonstrated that they had a behavior similar to MSCs in terms of multipotency. Similar to MSCs, $\mathrm{AuCPCs}$ had the ability to differentiate towards multiple lineages, as confirmed by positive stainings for bone, adipose tissue and cartilage. Furthermore, AuCPCs, being $\mathrm{CD}_{73}^{+}, \mathrm{CD}^{\circ} 0^{+}, \mathrm{CD} 105^{+}, \mathrm{CD}^{-} 4^{-}$and $C D 45^{-}$, displayed a gene expression profile for surface markers that is consistent with the minimal criteria for human MSCs (Dominici et al., 2006). Additional cell surface marker analysis showed similar gene expression profiles between AuCPCs and bone marrow-derived MSCs. A main difference among
$\mathrm{AuCHs}, \mathrm{AuCPCs}$ and MSCs arose in the expression of $C D 13$, which is a marker widely expressed by a variety of cell subpopulations, including stem cells (Calloni et al., 2013; Dondossola et al., 2013). These data, in addition to the ability to differentiate towards multiple lineages, demonstrated a behavior similar to bone marrow-derived MSCs, both genetically and functionally.

The limited knowledge on AuCPCs demands further investigation into specific cell characteristics, yet our study focused on advancing towards the utilization of these cells. Their stem cell characteristics, in addition to a differentiation capacity likely primed towards their source tissue, makes AuCPCs a highly interesting cell source for cartilage tissue engineering strategies. These cells provide an opportunity to overcome the drawbacks of the cell types currently used in cartilage tissue engineering and, thereby, can increase the likelihood of using tissue-engineered auricular cartilage structures for clinical application. Hence, the behavior of AuCPCs in 3D culture for tissue regeneration was explored in comparison to $\mathrm{AuCH}$ and MSCs. Growth and differentiation in the $3 \mathrm{D}$ provides a more natural environment for cells and allows the preservation of tissue-specific characteristics (Pampaloni et al., 2007). In this study, cells were encapsulated in a 3D hydrogel system (gelMA) proven to be a permissive environment for neocartilage production (Klotz et al., 2016; Levato et al., 2017; Levett et al., 2013; Schuurman et al., 2013). GelMA is a widespread platform for tissue engineering and bioprinting applications, owing to its natural bioactivity and tailorability (Klotz et al., 2016). This versatile hydrogel can be functionalized for improved performance in supporting cells [for instance with hyaluronic acid (Levett et al., 2013)], printing resolution [e.g. with gellan gum (Mouser et al., 2016)] or mechanical stability [by incorporating reinforcing fibers (Visser et al., 2015), scaffolding materials, such as stiff and elastic hydrogels (Melchels and Blokzijl et al., 2016), or thermoplastic polymers (Mouser et al., 2017)]. Its biocompatibility and clinical grade options make gelMA a beneficial biomaterial choice with respect to future clinical translation (Klotz et al., 2016).

In 3D hydrogel culture, all three cell types demonstrated increasing extracellular matrix production over the culture period, as indicated by sGAG/dsDNA quantification and confirmed by histology. Whereas AuCHs and AuCPCs displayed a similar matrix-synthesizing behavior, MSCs outperformed both cell types in terms of sGAG deposition. Proteoglycan aggregates are the major structural matrix components contributing to the mechanical properties of the tissue and the trend in matrix synthesis clearly matched the compressive moduli among cell types at the end of the culture period. Nevertheless, the observed differences in total sGAG content at $28 \mathrm{~d}$ of culture did not reflect the concurrent mechanical properties. At this time point, $\mathrm{AuCPCs}$ were outperforming MSCs in terms of total 
sGAG content and compressive Young's modulus, but the marked difference in Young's modulus between $\mathrm{AuCPC}$ and $\mathrm{AuCH}$ s was not observed in the total sGAG content. Since the mechanical properties of cartilage tissue are impacted by the organization of the tissue (Wu and Herzog, 2002), a potential explanation is a more homogeneous distribution of proteoglycans and collagens in both AuCPCs and MSCs upon histological examination, whereas $\mathrm{AuCH}$ displayed a more cluster-like organization of matrix components. In our study, the mechanical properties of tissue-engineered cartilage constructs ranged between 102.8 and $179.2 \mathrm{kPa}$, which was at least a factor 10 inferior to native auricular cartilage. Griffin et al. (2016) report the compressive moduli of native human auricular cartilage to range between 1.41 and $2.08 \mathrm{MPa}$, whereas Nimeskern et al. (2015a) determine an instantaneous modulus of 3.27-11.02 MPa, a maximum stress of $0.87-3.11 \mathrm{MPa}$ and an equilibrium modulus of 2.22-7.23 MPa. Thus, tissue-engineered cartilage constructs require improved mechanical properties, which can be attained through supporting frameworks (Cervantes et al., 2013), by fiber reinforcement (Visser et al., 2015) or possibly through mechanical loading of the developing neo-tissue, which is shown to increase cellular production of matrix components in articular cartilage (Musumeci, 2016).

Differential mRNA expression of cartilage-specific markers confirmed cell differentiation towards the chondrogenic lineage in all three cell types. Although collagen type II expression was highly upregulated over the 56-d culture period, all three cell types demonstrated concurrent collagen type I expression, confirmed by immunohistochemistry. Improvement of neocartilage quality may be attained through functionalization of the hydrogel or by optimizing the recipe of the differential culture media. For example, the incorporation of hyaluronic acid in gelMA is shown to decrease collagen type I production (Levett et al., 2013), whereas supplementation with insulinlike growth factor-1 (IGF-1) enhances the generation of elastic fibers in addition to improved overall tissue formation (Rosa et al., 2014).

The auricle is a strong, yet flexible structure composed of cartilage of the elastic type. Its composition is similar to that of hyaline cartilage, consisting of negatively charged proteoglycan aggregates attracting water and a dense collagen type II network (Nabzdyk et al., 2009). Nevertheless, the auricular cartilage is unique in that it harbors an intricate network of elastic fibers. Elastin has a defining role in the mechanical properties of elastic cartilage, allowing flexibility and a swift return to its original shape after minor loads (Nimeskern et al., 2015b). AuCPCs exhibited an upregulated expression of elastin in the cell-laden hydrogels. This feature offers the potential prime advantage of using AuCPCs over MSCs for tissue engineering of auricular cartilage, since the latter did not display elastin upregulation. Quantification and/or visualization of the production of elastin in tissue-engineered constructs could confirm this potential and would be advisable for future studies.

One common problem with cartilage tissue engineering is calcification of the neo-tissue (Jessop et al., 2016). Primary chondrocytes may terminally differentiate and become hypertrophic, which can lead to calcification and eventually ossification of the neo-tissue (Gerstenfeld and Shapiro, 1996; Phull et al., 2016). Collagen type $X$ is a typical marker of chondrocyte hypertrophy (Martin et al., 2001), although its presence is demonstrated in native non-mineralized auricular cartilage (Dahl et al., 2011; Hellingman et al., 2011). Several studies report the expression of collagen type $\mathrm{X}$ in cartilage tissue engineered from auricular chondrocytes, yet this does not result in mineralization of neo-tissues in both in vitro and in vivo conditions (Dahl et al., 2011; Hellingman et al., 2011). Indeed, in this study, the mRNA expression of collagen type $X$ was highly upregulated in $\mathrm{AuCHs}$, indicating chondrocyte hypertrophy. Nonetheless, our findings confirmed that this did not result in mineralization of the neotissue up to $56 \mathrm{~d}$ of in vitro culture. The relatively low expression of COL10A1 in both AuCPCs and MSCs might indicate preservation of the phenotype in these cell types under in vitro chondrogenic conditions. Nevertheless, the expression of RUNX2 was significantly upregulated in MSCs as compared to AuCPCs and AuCHs at $56 \mathrm{~d}$ of culture. RUNX2 drives osteogenic differentiation and inhibits differentiation of MSCs into chondrocytes (Komori, 2006). In contrast, AuCPCs demonstrated a significant reduction in RUNX2 expression over time. MSCs from the bone marrow form bone in vivo through the endochondral ossification pathway (Gawlitta et al., 2010), whereas AuCPCs originate from the cartilage itself and their niche may have primed them towards the target tissue, maintaining their specific phenotype. The lack of hypertrophy in AuCPC cultures, as well as the decreased RUNX2 and increased elastin expression levels pointed to a stable phenotype that is amenable for tissue engineering.

In conclusion, the identification of a cartilage progenitor subpopulation in the auricular cartilage provided access to a promising cell source for tissue engineering strategies for auricular reconstruction. Although under the current culturing conditions, bone marrow-derived MSCs seemed to perform better in terms of matrix production, major advantages of AuCPCs include the ability to generate high cell numbers (Williams et al., 2010; Xue et al., 2016), upregulation of the elastin gene and a limited endochondral ossification potential. Taken together, these advantages make progenitor cells from the auricular cartilage a highly interesting candidate as a cell source for future tissue-engineering-based clinical therapies. 


\section{Acknowledgements}

All authors declare no conflict of interest. The research was supported by the Netherlands Organization for Scientific Research, the Dutch Arthritis Foundation (CO-14-001, LLP-12 and LLP-22), the European Community's Seventh Framework Program (FP7/ 2007-2013) under grant agreement No. 309962 (HydroZONES) and the European Research Council under grant agreement No. 647426 (3D-JOINT).

\section{References}

Ahmed TAE, Hincke MT (2014) Mesenchymal stem cell-based tissue engineering strategies for repair of articular cartilage. Histol Histopathol 29: 669-689.

Ávila HM, Feldmann E-M, Pleumeekers MM, Nimeskern L, Kuo W, de Jong WC, Schwarz S, Müller R, Hendriks J, Rotter N, van Osch GJVM, Stok KS, Gatenholm P (2015) Novel bilayer bacterial nanocellulose scaffold supports neocartilage formation in vitro and in vivo. Biomaterials 44: 122133.

Benya PD, Shaffer JD (1982) Dedifferentiated chondrocytes reexpress the differentiated collagen phenotype when cultured in agarose gels. Cell 30: 215-224.

Bichara DA, Zhao X, Hwang NS, BodugozSenturk H, Yaremchuk MJ, Randolph MA, Muratoglu OK (2010) Porous poly(vinyl alcohol)-alginate gel hybrid construct for neocartilage formation using human nasoseptal cells. J Surg Res 163: 331-336.

Bichara DA, O'Sullivan N-A, Pomerantseva I, Zhao X, Sundback CA, Vacanti JP, Randolph MA (2012) The tissue-engineered auricle: past, present, and future. Tissue Eng Part B Rev 18: 51-61.

Bichara DA, Pomerantseva I, Zhao X, Zhou L, Kulig KM, Tseng A, Kimura AM, Johnson MA, Vacanti JP, Randolph MA, Sundback CA (2014) Successful creation of tissue-engineered autologous auricular cartilage in an immunocompetent large animal model. Tissue Eng Part A 20: 303-312.

Calloni R, Cordero EAA, Henriques JAP, Bonatto D (2013) Reviewing and updating the major molecular markers for stem cells. Stem Cells Dev 22: 1455-1476.

Cao Y, Vacanti JP, Paige KT, Upton J, Vacanti CA (1997) Transplantation of chondrocytes utilizing a polymer-cell construct to produce tissue-engineered cartilage in the shape of a human ear. Plast Reconstr Surg 100: 297-294.

Cervantes TM, Bassett EK, Tseng A, Kimura A, Roscioli N, Randolph MA, Vacanti JP, Hadlock TA, Gupta R, Pomerantseva I, Sundback CA (2013) Design of composite scaffolds and three-dimensional shape analysis for tissue-engineered ear. J R Soc Interface 10: 20130413.

Cheng Y, Cheng P, Xue F, Wu K-M, Jiang M-J, Ji J-F, Hang C-H, Wang Q-P (2014) Repair of ear cartilage defects with allogenic bone marrow mesenchymal stem cells in rabbits. Cell Biochem Biophys 70: 11371143.

Christodoulou I, Kolisis FN, Papaevangeliou D, Zoumpourlis V (2013) Comparative evaluation of human mesenchymal stem cells of fetal (Wharton's jelly) and adult (adipose tissue) origin during prolonged in vitro expansion: considerations for cytotherapy. Stem Cells Int 1: 246134.

Chung C, Mesa J, Miller GJ, Randolph MA, Gill TJ, Burdick JA (2006) Effects of auricular chondrocyte expansion on neocartilage formation in photocrosslinked hyaluronic acid networks. Tissue Eng 12: 2665-2673.

Dahl JP, Caballero M, Pappa AK, Madam G, Shockley WW, van Aalst JA (2011) Analysis of human auricular cartilage to guide tissue-engineered nanofiber-based chondrogenesis: implications for microtia reconstruction. Otolaryngol Head Neck Surg 145: 915-923.

Daly AC, Critchley SE, Rencsok EM, Kelly DJ (2016) A comparison of different bioinks for 3D bioprinting of fibrocartilage and hyaline cartilage. Biofabrication 8: 045002.

Demoor M, Ollitrault D, Gomez-Leduc T, Bouyoucef M, Hervieu M, Fabre H, Lafont J, Denoix J-M, Audigié F, Mallein-Gerin F, Legendre F, Galera P (2014) Cartilage tissue engineering: molecular control of chondrocyte differentiation for proper cartilage matrix reconstruction. Biochim Biophys Acta 1840: 2414-2440.

Derks M, Sturm T, Haverich A, Hilfiker A (2013) Isolation and chondrogenic differentiation of porcine perichondrial progenitor cells for the purpose of cartilage tissue engineering. Cells Tissues Organs 198: 179-189.

DiCesare PE, Mörgelin M, Carlson CS, Pasumarti S, Paulsson M (1995) Cartilage oligomeric matrix protein: isolation and characterization from human articular cartilage. J Orthop Res 13: 422-428.

Dominici M, Le Blanc K, Mueller I, SlaperCortenbach I, Marini F, Krause D, Deans R, Keating A, Prockop D, Horwitz E (2006) Minimal criteria for defining multipotent mesenchymal stromal cells. The International Society for Cellular Therapy position statement. Cytotherapy 8: 315-317.

Dondossola E, Rangel R, Guzman-Rojas L, Barbu EM, Hosoya H, St John LS, Molldrem JJ, Corti A, Sidman RL, Arap W, Pasqualini R (2013) CD13positive bone marrow-derived myeloid cells promote angiogenesis, tumor growth, and metastasis. Proc Natl Acad Sci U S A 110: 20717-20722.

Dowthwaite GP, Bishop JC, Redman SN, Khan IM, Rooney P, Evans DJR, Haughton L, Bayram Z, Boyer S, Thomson B, Wolfe MS, Archer CW (2004) The surface of articular cartilage contains a progenitor cell population. J Cell Sci 117: 889-897.

Gao G, Schilling AF, Hubbell K, Yonezawa T, Truong D, Hong Y, Dai G, Cui X (2015) Improved properties of bone and cartilage tissue from 3D inkjet-bioprinted human mesenchymal stem cells 
by simultaneous deposition and photocrosslinking in PEG-GelMA. Biotechnol Lett 37: 1-7.

García-López J, Garciadiego-Cázares D, Melgarejo Y, Sánchez-Sánchez R, Solís-Arrieta L, García-Carvajal Z, Sánchez-Betancourt JI, Ibarra C, Luna-Bárcenas G, Velasquillo C (2015) Chondrocyte differentiation for auricular cartilage reconstruction using a chitosan based hydrogel. Histol Histopathol 30: 11642-1485.

Gardner OFW, Archer CW, Alini M, Stoddart MJ (2013) Chondrogenesis of mesenchymal stem cells for cartilage tissue engineering. Histol Histopathol 28: $23-42$.

Gattazzo F, Urciuolo A, Bonaldo P (2014) Extracellular matrix: a dynamic environment for stem cell niche. Biochim Biophys Acta 1840: 2506-2519.

Gawlitta D, Farrell E, Malda J, Creemers LB, Alblas J, Dhert WJA (2010) Modulating endochondral ossification of multipotent stromal cells for bone regeneration. Tissue Eng Part B 16: 385-395.

Gerstenfeld LC, Shapiro FD (1996) Expression of bone-specific genes by hypertrophic chondrocytes: Implications of the complex functions of the hypertrophic chondrocyte during endochondral bone development. J Cell Biochem 62: 1-9.

Graham A (2001) The development and evolution of the pharyngeal arches. J Anat 199: 133-141.

Griffin MF, Premakumar Y, Seifalian AM, Szarko M, Butler PEM (2016) Biomechanical characterisation of the human auricular cartilages; implications for tissue engineering. Ann Biomed Eng 44: 1-8.

Haisch A, Kläring S, Gröger A, Gebert C, Sittinger $M$ (2002) A tissue-engineering model for the manufacture of auricular-shaped cartilage implants. Eur Arch Otorhinolaryngol 259: 316-321.

Hellingman CA, Verwiel ETP, Slagt I, Koevoet W, Poublon RML, Nolst-Trenité GJ, Baatenburg de Jong RJ, Jahr H, van Osch GJVM (2011) Differences in cartilage-forming capacity of expanded human chondrocytes from ear and nose and their gene expression profiles. Cell Transplant 20: 925-940.

Homicz MR, Schumacher BL, Sah RL, Watson D (2002) Effects of serial expansion of septal chondrocytes on tissue-engineered neocartilage composition. Otolaryngol Head Neck Surg 127: 398408.

Ishak MFB, See GB, Hui CK, Abdullah AB, Saim LB, Saim AB, Idrus RBH (2015) The formation of human auricular cartilage from microtic tissue: an in vivo study. 79: 1634-1639.

Isogai N, Kusuhara H, Ikada Y, Ohtani H, Jacquet R, Hillyer J, Lowder E, Landis WJ (2006) Comparison of different chondrocytes for use in tissue engineering of cartilage model structures. Tissue Eng 12: 691-703.

Jayasuriya CT, Chen Q (2015) Potential benefits and limitations of utilizing chondroprogenitors in cell-based cartilage therapy. Connect Tissue Res 56: 265-271.

Jakob M, Démarteau O, Schäfer D, Hintermann B, Dick W, Heberer M, Martin I (2001) Specific growth factors during the expansion and redifferentiation of adult human articular chondrocytes enhance chondrogenesis and cartilagenous tissue formation in vitro. J Cell Biochem 81: 368-377.

Jessop ZM, Javed M, Otto IA, Combellack EJ, Morgan S, Breugem CC, Archer CW, Khan IM, Lineaweaver WC, Kon M, Malda J, Whitaker IS (2016) Combining regenerative medicine strategies to provide durable reconstructive options: auricular cartilage tissue engineering. Stem Cell Res Ther 7: 19.

Jiang Y, Tuan RS (2015) Origin and function of cartilage stem/progenitor cells in osteoarthritis. Nat Rev Rheumatol 11: 206-212.

Kamil SH, Vacanti MP, Aminuddin BS, Jackson MJ, Vacanti CA, Eavey RD (2004a) Tissue engineering of a human sized and shaped auricle using a mold. Laryngoscope 114: 867-870.

Kamil SH, Vacanti MP, Vacanti CA, Eavey RD (2004b) Microtia chondrocytes as a donor source for tissue-engineered cartilage. Laryngoscope 114: 21872190.

Kang N, Liu X, Guan Y, Wang J, Gong F, Yang X, Yan L, Wang Q, Fu X, Cao Y, Xiao R (2012) Effects of co-culturing BMSCs and auricular chondrocytes on the elastic modulus and hypertrophy of tissue engineered cartilage. Biomaterials 33: 4535-4544.

Klotz BJ, Gawlitta D, Rosenberg AJWP, Malda J, Melchels FPW (2016) Gelatin-methacryloyl hydrogels: towards biofabrication-based tissue repair. Trends Biotechnol 34: 394-407.

Kobayashi S, Takebe T, Inui M, Iwai S, Kan H, Zheng Y-W, Maegawa J, Taniguchi H (2011a) Reconstruction of human elastic cartilage by a CD44 $\mathrm{CD}^{+} 0^{+}$stem cell in the ear perichondrium. Proc Natl Acad Sci U S A 108: 14479-14484.

Kobayashi S, Takebe T, Zheng Y-W, Mizuno M, Yabuki Y, Maegawa J, Taniguchi H (2011b) Presence of cartilage stem/progenitor cells in adult mice auricular perichondrium. PLoS One 6: e26393.

Kusuhara H, Isogai N, Enjo M, Otani H, Ikada Y, Jacquet R, Lowder E, Landis WJ (2008) Tissue engineering a model for the human ear: assessment of size, shape, morphology, and gene expression following seeding of different chondrocytes. Wound Repair Regen 17: 136-146.

Hedbom E, Antonsson P, Hjerpe A, Aeschlimann D, Paulsson M, Rosa-Pimentel E, Sommarin Y, Wendel M, Oldberg Å, Heinegård D (1992) Cartilage matrix proteins. An acidic oligomeric protein (COMP) detected only in cartilage. J Biol Chem 267: 6132-6136.

Lee J, Lee E, Kim HY, Son Y (2007) Comparison of articular cartilage with costal cartilage in initial cell yield, degree of dedifferentiation during expansion and redifferentiation capacity. Biotechnol Appl Biochem 48: 149-158.

Levato R, Webb WR, Otto IA, Mensinga A, Zhang $Y$, van Rijen $M$, van Weeren $R$, Khan IM, Malda $\mathrm{J}$ (2017) The bio in the ink: cartilage regeneration with bioprintable hydrogels and articular cartilagederived progenitors cells. Acta Biomaterialia 61: 4153.

Levett PA, Melchels FPW, Schrobback K, Hutmacher DW, Malda J, Klein TJ (2013) A biomimetic 
extracellular matrix for cartilage tissue engineering centered on photocurable gelatin, hyaluronic acid and chondroitin sulfate. Acta Biomaterialia 10: 214-223.

Liu X, Sun H, Yan D, Zhang L, Lv X, Liu T, Zhang W, Liu W, Cao Y, Zhou G (2010) In vivo ectopic chondrogenesis of BMSCs directed by mature chondrocytes. Biomaterials 31: 9406-9414.

Luquetti DV, Heike CL, Hing AV, Cunningham ML, Cox TC (2011) Microtia: epidemiology and genetics. Am J Med Genet A 158A: 124-139.

Lv X, Zhou G, Liu X, Liu H, Chen J, Liu K, Cao Y (2012) Chondrogenesis by co-culture of adiposederived stromal cells and chondrocytes in vitro. Connect Tissue Res 53: 492-497.

Martin I, Jakob M, Schäfer D, Dick W, Spagnoli G, Heberer M (2001) Quantitative analysis of gene expression in human articular cartilage from normal and osteoarthritic joints. Osteoarthritis Cartilage 9: 112-118.

McCarthy HE, Bara JJ, Brakspear K, Singhrao SK, Archer CW (2012) The comparison of equine articular cartilage progenitor cells and bone marrow-derived stromal cells as potential cell sources for cartilage repair in the horse. Vet J 192: 345-351.

Melchels FPW, Dhert WJA, Hutmacher DW, Malda J (2014) Development and characterisation of a new bioink for additive tissue manufacturing. J Mater Chem B 2: 2282-2289.

Melchels FPW, Blokzijl MM, Levato R, Peiffer QC, De Ruijter M, Hennink WE, Vermonden T, Malda J (2016) Hydrogel-based reinforcement of 3D bioprinted constructs. Biofabrication 8: 035004.

Mizuno M, Takebe T, Kobayashi S, Kimura S, Masutani M, Lee S, Jo YH, Lee JI, Taniguchi H (2014) Elastic cartilage reconstruction by transplantation of cultured hyaline cartilage-derived chondrocytes. Transplant Proc 46: 1217-1221.

Mouser VHM, Melchels FPW, Visser J, Dhert WJA, Gawlitta D, Malda J (2016) Yield stress determines bioprintability of hydrogels based on gelatin-methacryloyl and gellan gum for cartilage bioprinting. Biofabrication 8: 035003.

Mouser VHM, Abbadessa A, Levato R, Hennink WE, Vermonden T, Gawlitta D, Malda J (2017) Development of a thermosensitive HAMA-containing bio-ink for the fabrication of composite cartilage repair constructs. Biofabrication 9: 015026.

Mueller MB, Tuan RS (2008) Functional characterization of hypertrophy in chondrogenesis of human mesenchymal stem cells. Arthritis Rheum 58: $1377-1388$.

Musumeci G (2016) The effect of mechanical loading on articular cartilage. J Funct Morphol Kinesiol 1: 154-161.

Nabzdyk C, Pradhan L, Molina J, Perin E, Paniagua D, Rosenstrauch D (2009) Review: auricular chondrocytes - from benchwork to clinical applications. In Vivo 23: 369-380.

Nakao H, Jacquet RD, Shasti M, Isogai N, Murthy AS, Landis WJ (2017) Long-term comparison between human normal conchal and microtia chondrocytes regenerated by tissue engineering on nanofiber polyglycolic acid scaffolds. Plast Reconstr Surg 139: 911e-921e.

Newton G, Weremowicz S, Morton CC, Copeland NG, Gilbert DJ, Jenkins NA, Lawler J (1994) Characterization of human and mouse cartilage oligomeric matrix protein. Genomics 24: 435-439.

Nimeskern L, Pleumeekers MM, Pawson DJ, Koevoet WLM, Lehtoviita I, Soyka MB, Röösli C, Holzmann D, van Osch GJVM, Müller R, Stok KS (2015a) Mechanical and biochemical mapping of human auricular cartilage for reliable assessment of tissue-engineered constructs. J Biomech 48: 1721-1729.

Nimeskern L, Utomo L, Lehtoviita I, Fessel G, Snedeker JG, van Osch GJVM, Müller R, Stok KS (2015b) Tissue composition regulates distinct viscoelastic responses in auricular and articular cartilage. J Biomech 49: 344-352.

Pampaloni F, Reynaud EG, Stelzer EHK (2007) The third dimension bridges the gap between cell culture and live tissue. Nat Rev Mol Cell Biol 8: 839-845.

Papadopoulos A, Bichara DA, Zhao X, Ibusuki S, Randolph MA, Anseth KS, Yaremchuk MJ (2011) Injectable and photopolymerizable tissue-engineered auricular cartilage using poly(ethylene glycol) dimethacrylate copolymer hydrogels. Tissue Eng Part A 17: 161-169.

Pappa AK, Caballero M, Dennis RG, Skancke MD, Narayan RJ, Dahl JP, van Aalst JA (2013) Biochemical properties of tissue-engineered cartilage. J Craniofac Surg 25: 111-115.

Park SS, Jin H-R, Chi DH, Taylor RS (2004) Characteristics of tissue-engineered cartilage from human auricular chondrocytes. Biomaterials 25: 23632369.

Phull A-R, Eo S-H, Abbas Q, Ahmed M, Kim SJ (2016) Applications of chondrocyte-based cartilage engineering: an overview. Biomed Res Int 2016: 1879837-17.

Pittenger MF, Mackay AM, Beck SC, Jaiswal RK, Douglas R, Mosca JD, Moorman MA, Simonetti DW, Craig S, Marshak DR (1999) Multilineage potential of adult human mesenchymal stem cells. Science $\mathbf{2 8 4}$ : 143-147.

Pleumeekers MM, Nimeskern L, Koevoet WLM, Kops N, Poublon RML, Stok KS, van Osch GJVM (2013) The in vitro and in vivo capacity of culture-expanded human cells from several sources encapsulated in alginate to form cartilage. Eur Cell Mater 27: 264-280.

Pleumeekers MM, Nimeskern L, Koevoet WLM, Karperien M, Stok KS, van Osch GJVM (2015) Cartilage regeneration in the head and neck area: combination of ear or nasal chondrocytes and mesenchymal stem cells improves cartilage production. Plast Reconstr Surg 136: 762e-774e

Pomerantseva I, Bichara DA, Tseng A, Cronce MJ, Cervantes TM, Kimura AM, Neville CM, Roscioli N, Vacanti JP, Randolph MA, Sundback 
CA (2016) Ear-shaped stable auricular cartilage engineered from extensively expanded chondrocytes in an immunocompetent experimental animal model. Tissue Eng Part A 22: 197-207.

Reiffel AJ, Kafka C, Hernandez KA, Popa S, Perez JL, Zhou S, Pramanik S, Brown BN, Ryu WS, Bonassar LJ, Spector JA (2012) High-fidelity tissue engineering of patient-specific auricles for reconstruction of pediatric microtia and other auricular deformities. PLoS One 8: e56506.

Rosa RG, Joazeiro PP, Bianco J, Kunz M, Weber JF, Waldman SD (2014) Growth factor stimulation improves the structure and properties of scaffold-free engineered auricular cartilage constructs. PLoS One 9: e105170.

Saadeh PB, Brent B, Mehrara BJ, Steinbrech DS, Ting V, Gittes GK, Longaker MT (1999) Human cartilage engineering: chondrocyte extraction, proliferation, and characterization for construct development. Ann Plast Surg 42: 509-513.

Sanz E, Peñas L, Lequerica JL (2007) Formation of cartilage in vivo with immobilized autologous rabbit auricular cultured chondrocytes in collagen matrices. Plast Reconstr Surg 119: 1707-1713.

Schnabel M, Marlovits S, Eckhoff G, Fichtel I, Gotzen L, Vécsei V, Schlegel J (2002) Dedifferentiationassociated changes in morphology and gene expression in primary human articular chondrocytes in cell culture. Osteoarthritis Cartilage 10: 62-70.

Schuurman W, Levett PA, Pot MW, van Weeren PR, Dhert WJA, Hutmacher DW, Melchels FPW, Klein TJ, Malda J (2013) Gelatin-methacrylamide hydrogels as potential biomaterials for fabrication of tissue-engineered cartilage constructs. Macromol Biosci 13: 551-561

Seda Tigli R, Ghosh S, Laha MM, Shevde NK, Daheron L, Gimble J, Gümüşderelioglu M, Kaplan DL (2009) Comparative chondrogenesis of human cell sources in 3D scaffolds. J Tissue Eng Regen Med 3: 348-360.

Schulze-Tanzil G, Mobasheri A, De Souza P, John T, Shakibaei M (2004) Loss of chondrogenic potential in dedifferentiated chondrocytes correlates with deficient Shc-Erk interaction and apoptosis. Osteoarthritis Cartilage 12: 448-458.

Togo T, Utani A, Naitoh M, Ohta M, Tsuji Y, Morikawa N, Nakamura M, Suzuki S (2006) Identification of cartilage progenitor cells in the adult ear perichondrium: utilization for cartilage reconstruction. Lab Invest 86: 445-457.

Tracy JC, Lee AS, Scott AR, Karmody CS (2013) Embryology and anomalies of the external ear. Advanced Cosmetic Otoplasty. In: Shiffman M. (eds) Advanced cosmetic otoplasty. Springer, Berlin, Heidelberg.

Tseng A, Pomerantseva I, Cronce MJ, Kimura AM, Neville CM, Randolph MA, Vacanti JP, Sundback CA (2014) Extensively expanded auricular chondrocytes form neocartilage in vivo. Cartilage 5: 241-251.

van Osch GJVM, Van der Veen SW, VerwoerdVerhoef HL (2001) In vitro redifferentiation of culture- expanded rabbit and human auricular chondrocytes for cartilage reconstruction. Plast Reconstr Surg 107: 433-440.

Vinardell T, Sheehy EJ, Buckley CT, Kelly DJ (2012) A comparison of the functionality and in vivo phenotypic stability of cartilaginous tissues engineered from different stem cell sources. Tissue Eng Part A 18: 1161-1170.

Visser J, Gawlitta D, Benders KEM, Toma SMH, Pouran B, van Weeren PR, Dhert WJA, Malda J (2014) Endochondral bone formation in gelatin methacrylamide hydrogel with embedded cartilagederived matrix particles. Biomaterials 37: 174-182.

Visser J, Melchels FPW, Jeon JE, van Bussel EM, Kimpton LS, Byrne HM, Dhert WJA, Dalton PD, Hutmacher DW, Malda J (2015) Reinforcement of hydrogels using three-dimensionally printed microfibres. Nat Commun 6: 6933.

Williams R, Khan IM, Richardson K, Nelson L, McCarthy HE, Analbelsi T, Singhrao SK, Dowthwaite GP, Jones RE, Baird DM, Lewis H, Roberts S, Shaw HM, Dudhia J, Fairclough J, Briggs T, Archer CW (2010) Identification and clonal characterisation of a progenitor cell sub-population in normal human articular cartilage. Ed. Sudha Agarwal. PLoS One 5: e13246.

Wright CG (1997) Development of the human external ear. J Am Acad Audiol 8: 379-382.

Wu JZ, Herzog W (2002) Elastic anisotropy of articular cartilage is associated with the microstructures of collagen fibers and chondrocytes. J Biomech 35: 931-942.

Xu JW, Johnson TS, Motarjem PM, Peretti GM, Randolph MA, Yaremchuk MJ (2005) Tissueengineered flexible ear-shaped cartilage. Plast Reconstr Surg 115: 1633-1641.

Xue K, Zhang X, Qi L, Zhou J, Liu K (2016) Isolation, identification, and comparison of cartilage stem progenitor/cells from auricular cartilage and perichondrium. Am J Transl Res 8: 732-741.

Zhao S, Fernald RD (2005) Comprehensive algorithm for quantitative real-time polymerase chain reaction. J Comput Biol 12: 1045-1062.

Zhao X, Hwang NS, Bichara DA, Saris DB, Malda J, Vacanti JP, Pomerantseva I, Sundback CA, Langer R, Anderson DG, Randolph MA (2016) Chondrogenesis by bone marrow-derived mesenchymal stem cells grown in chondrocyte-conditioned medium for auricular reconstruction. J Tissue Eng Regen Med: 11: $2763-2773$.

\section{Discussion with Reviewers}

Oliver Gardner: Articular cartilage progenitor cells have a highly specific location within the tissue, which relates to their role in the growth and maintenance of the tissue. Do the authors believe that AuCPCs have a specific niche and role within auricular cartilage? Authors: For auricular cartilage progenitor cells there is currently no proof of a specific localization, also due 
to the limited amount of studies focusing on these cells. Since there is a lack of specific markers for these cells, such a localization cannot yet be easily defined. As it may be possible that AuCPCs have a specific niche within the auricular cartilage, future studies on the developmental origin, exact tissue localization and role of AuCPCs would be very interesting for the field of cartilage biology.

Karoliina Pelttari: Can a big enough biopsy be harvested from patients without donor site morbidity? What about patients with bilateral microtia?

Authors: Cartilage progenitor cells are thought to form up to $\pm 0.7 \%$ of the cell population in the articular cartilage and are reported to be able to proliferate to over 60 population doublings (Williams et al., 2010). Similar characteristics in progenitors from other cartilage sources are expected. AuCPCs demonstrated a potent ability to proliferate up to passage 4 - when, in the present study, the cells were utilized for tissue engineering purposes meaning that large amounts of functional cells can be generated. Although exact calculations on the number of progenitor cells obtainable from a specific cartilage volume are outside the scope of this study, the proliferation potential of progenitor cells suggest that, with only a small biopsy from the auricular cartilage, a sufficient number of cells can be generated for the production of a full-sized tissue-engineered auricle. Cells can be obtained from healthy auricular cartilage or from the microtia remnant, although the presence of progenitor cells in the latter tissue has not yet been reported. Depending on the proliferative and cartilage-forming ability of microtia-derived cells, this source can potentially overcome donor site morbidity in both unilateral and bilateral microtia patients.

Karoliina Pelttari: Are cells from patients with congenital microtia different from healthy auricular chondrocyte? Gu et al. (2017) (additional reference) show an inferior cartilage-forming capacity of microtia-chondrocytes.

Authors: The microtic auricle is a congenital deformity. Its etiology is not fully understood, yet there is evidence for the involvement of environmental factors besides genetic factors (Luquetti et al., 2012, additional reference). On a macroscopic level, the microtic cartilage is reported to possess similar cell morphology and tissue organization (MelgarejoRamirez et al., 2016, additional reference). Various studies observed no marked differences between healthy and microtia chondrocytes in terms of growth rates, expression of cartilage genes and ability to generate cartilage-like tissue in vivo (Kamil et al., 2004; Ishak et al., 2011, additional reference; Ishak et al., 2015; Nakao et al., 2017). Indeed, Gu et al. (2017) report a biochemically and biomechanically inferior quality neocartilage produced by microtia chondrocytes. These contrasting results indicate the need for a further exploration of differences between microtia and healthy chondrocytes and their ability for cartilage production under various conditions.

Karoliina Pelttari: Have such AuCPC with similar characteristics been identified in human?

Authors: Cartilage progenitor cells are a relatively established cell population in the articular cartilage of various animal species (Dowthwaite et al., 2004; Williams et al., 2010; McCarthy et al., 2012; Tran et al., 2014, additional reference), yet only little is known about the presence of these cells in the auricular cartilage. Cartilage-derived progenitor cells are identified in porcine and now equine auricular cartilage. Following this observation, the presence of such a subpopulation in the human auricular cartilage is likely.

Karoliina Pelttari: Is the hydrogel used in this study an already approved material for clinical use?

Authors: The hydrogel used in this study, gelatin methacryloyl (gelMA), is not yet approved for clinical use. Nevertheless, it demonstrates good biocompatibility when synthesized with the endotoxin-free gelatin type B (Sirova et al., 2014, additional reference). Although the biocompatibility of gelMA and its degradation products requires more extensive analysis, the biomaterial has potential for clinical application. In this study, this hydrogel was chosen as it continuously proves to be a suitable 3D system for tissue engineering, as multiple research groups repeatedly demonstrate (amongst others: Yue et al., 2015; Loessner et al., 2016; Klotz et al., 2016; Brown et al., 2017, additional references).

\section{Additional references}

Brown GCJ, Lim KS, Farrugia BL, Hooper GJ, Woodfield TBF (2017) Covalent incorporation of heparin improves chondrogenesis in photo curable gelatin-methacryloyl hydrogels. Macromol Biosci 17: 1700158.

Ishak MF, Chua KH, Asma A, Saim L, Aminuddin BS, Ruszymah BHI, Goh BS (2011) Stem cell genes are poorly expressed in chondrocytes from microtic cartilage. Int J Pediatr Otorhinolaryngol 75: 835-840.

Klotz BJ, Gawlitta D, Rosenberg AJWP, Malda J, Melchels FPW (2016) Gelatin-methacryloyl hydrogels: towards biofabrication-based tissue repair. Trends Biotechnol 34: 394-407.

Loessner D, Meiner C, Kaemmerer E, Martine LC, Yue K, Levett PA, Klein TJ, Melchels FPW, Khademhosseini A, Hutmacher DW (2016) Functionalization, preparation and use of cell-laden gelatin methacryloyl-based hydrogels as modular tissue culture platforms. Nat Protoc 11: 727-746.

Luquetti DV, Heike CL, Hing AV, Cunningham ML, Cox TC (2011) Microtia: epidemiology and genetics. Am J Med Genet Part A 158A: 124-139. 
Gu Y, Kang N, Dong P, Liu X, Wang Q, Fu X, Yan L, Jiang H, Ciao Y, Xiao R (2017) Chondrocytes from congenital microtia possess an inferior capacity for in vivo cartilage regeneration to healthy ear chondrocytes. J Tissue Eng Regen Med 210: 282.

Melgarejo-Ramírez Y, Sánchez-Sánchez R, GarcíaLópez J, Brena-Molina AM, Gutiérrez-Gómez C, Ibarra C, Velasquillo C (2016) Characterization of pediatric microtia cartilage: a reservoir of chondrocytes for auricular reconstruction using tissue engineering strategies. Cell Tissue Bank 17: 1-9.

Sirova M, Van Vlierberghe S, Matyasova V, Rossmann P, Schacht E, Dubruel P, Rihova B (2014) Immunocompatibility evaluation of hydrogel-coated polyimide implants for applications in regenerative medicine. J Biomed Mater Res Part A 102: 1982-1990.

Tran AN, Truong M-D, Choi BH, Park SR, Min B-H (2014) Identification and characterisation of novel stem/progenitor cells in rat adult articular cartilage. Osteoarthritis Cartilage 22: S442.

Yue K, Trujillo-de Santiago G, Alvarez MM, Tamayol A, Annabi N, Khademhosseini A (2015) Synthesis, properties, and biomedical applications of gelatine methacryloyl (GelMA) hydrogels. Biomaterials 73: 254-271.

Editor's note: The Scientific Editor responsible for this paper was Martin Stoddart. 